\title{
Ecology of Gymnodinium aureolum. I. Feeding in western Korean waters
}

\author{
Hae Jin Jeong ${ }^{1, *}$, Yeong Du Yoo ${ }^{1}$, Nam Seon Kang ${ }^{1}$, Jung Rae Rho' ${ }^{2}$, \\ Kyeong Ah Seong ${ }^{3}$, Jong Woo Park ${ }^{2}$, Gui Sook Nam ${ }^{4}$, Wonho Yih ${ }^{2}$
}

\author{
${ }^{1}$ School of Earth and Environmental Sciences, College of Natural Sciences, Seoul National University, Seoul 151-747, Korea \\ ${ }^{2}$ Department of Oceanography, Kunsan National University, Kunsan 573-701, Korea \\ ${ }^{3}$ Saemankeum Environmental Research Center, Kunsan National University, Kunsan 573-701, Korea \\ ${ }^{4}$ Rural Research Institute, Korea Rural Community Cooperation, Ansan 426-908, Korea
}

\begin{abstract}
A bloom-forming dinoflagellate was isolated from coastal waters in western Korea during a red tide event in March 2008 and clonal cultures were established. The dinoflagellate was identified as Gymnodinium aureolum based on morphological and genetic analyses (GenBank accession no. FN392226). We report here for the first time that the red-tide dinoflagellate G. aureolum, which has previously been thought to be exclusively autotrophic, is a mixotrophic species. G. aureolum fed on algal prey using a peduncle. Among the algal prey provided, G. aureolum ingested heterotrophic bacteria, the cyanobacterium Synechococcus sp., and small algal species that had equivalent spherical diameters (ESDs) of $\leq 11.5 \mu \mathrm{m}$. However, it did not feed on larger algal species (ESD $\geq 12 \mu \mathrm{m}$ ) or the small diatom Skeletonema costatum. The specific growth rates for G. aureolum on the cryptophyte Teleaulax sp. increased continuously with increasing mean prey concentration before saturating at prey concentrations of ca. $190 \mathrm{ng} \mathrm{C} \mathrm{ml}^{-1}\left(11050 \mathrm{cells} \mathrm{ml}^{-1}\right)$. The maximum specific growth rate (mixotrophic growth) of G. aureolum on Teleaulax sp. was $0.169 \mathrm{~d}^{-1}$, at $20^{\circ} \mathrm{C}$ under a $14: 10 \mathrm{~h}$ light:dark cycle of $20 \mu \mathrm{E} \mathrm{m}^{-2} \mathrm{~s}^{-1}$, while its growth rate (phototrophic growth) under the same light conditions without added prey was $0.120 \mathrm{~d}^{-1}$. The maximum ingestion and clearance rates of G. aureolum on Teleaulax sp. were $0.058 \mathrm{ng} \mathrm{C}$ grazer ${ }^{-1} \mathrm{~d}^{-1}\left(3.4\right.$ cells grazer $\left.{ }^{-1} \mathrm{~d}^{-1}\right)$ and $0.003 \mu \mathrm{lgrazer}{ }^{-1} \mathrm{~h}^{-1}$, respectively. The calculated in situ grazing coefficient for $G$. aureolum on co-occurring cryptophytes ranged up to $0.498 \mathrm{~d}^{-1}$. Bioassay results indicated that this strain of $G$. aureolum is not toxic. Results of the present study suggest that $G$. aureolum has a potentially considerable grazing impact on algal populations.
\end{abstract}

KEY WORDS: Growth $\cdot$ Harmful algal bloom $\cdot$ HAB $\cdot$ Ingestion $\cdot$ Mixotrophy $\cdot$ Peduncle $\cdot$ Protist

\section{INTRODUCTION}

The unarmored dinoflagellate Gyrodinium aureolum was first described by Hulburt (1957) and has been considered a common bloom-forming species in temperate waters (Tangen 1977, Potts \& Edwards 1987, Nielsen \& Tønseth 1991, Blasco et al. 1996). Hansen et al. (2000) concluded that the European isolates, which were formerly identified as Gyrodinium aureolum, Gyrodinium cf. aureolum, or Gymnodinium nagasakiense, were conspecific with the Japanese Gymnodinium mikimotoi, while an isolate from the Petta- quamscutt River, USA, was similar to the original description of Gyrodinium aureolum by Hulburt (1957). Thus it was suggested that the former isolates be designated as Gymnodinium mikimotoi, while the latter was transferred to Gymnodinium aureolum (Hansen et al. 2000). Meanwhile, Daugbjerg et al. (2000) reclassified the genera in the family Gymnodiniaceae on the basis of the shape of the apical groove, presence of nuclear chambers, presence of a nuclear fibrous connective (NFC), and types of pigments; species in the genera Gymnodinium have a horseshoeshaped apical groove, nuclear chambers, and an NFC, 
while species in the genera Karenia have a linear apical groove and do not have nuclear chambers or an NFC. Thus Gymnodinium mikimotoi, suggested by Hansen et al. (2000), came to be Karenia mikimotoi, while the name Gymnodinium aureolum was retained. Currently, it is easier to distinguish Gymnodinium aureolum from $K$. mikimotoi on the basis of morphology and genetic analyses. However, it is difficult to determine whether Gyrodinium aureolum isolates reported by researchers before Hansen et al. (2000) and Daugbjerg et al. (2000) were Gymnodinium aureolum or K. mikimotoi. An increasing number of taxonomic studies have been conducted on Gymnodinium aureolum strains isolated after the year 2000 (de Salas et al. 2003, Bergholtz et al. 2006, Tang et al. 2008).

Recently, many dinoflagellates thought to be exclusively autotrophic have been shown to be mixotrophic (Stoecker 1999, Jeong et al. 2004, 2005c, Burkholder et al. 2008). Mixotrophic species have been reported to consume a wide variety of prey items, including heterotrophic bacteria (Seong et al. 2006), cyanobacteria (Jeong et al. 2005b, Glibert et al. 2009), nano- and microflagellates (Stoecker et al. 1997, Li et al. 2000, Berge et al. 2008), other phototrophic dinoflagellates (Hansen \& Nielsen 1997, Jeong et al. 1999, 2005c,d, Skovgaard et al. 2000), diatoms (Bockstahler \& Coats 1993, Yoo et al. 2009), and ciliates (Smalley et al. 1999, Park et al. 2006). The trophic mode of Gymnodinium aureolum (i.e. exclusively autotrophic or mixotrophic) has not yet been investigated. This information is needed to understand the ecology and physiology of this dinoflagellate and may help determine the mechanism(s) controlling bloom formation.

During a 2008 red tide event on the west coast of Korea, we isolated and established a clonal culture of a dinoflagellate that morphological and genetic analysis revealed to be Gymnodinium aureolum (Hulburt 1957, Hansen et al. 2000, Daugbjerg et al. 2000, Tang et al. 2008). Thus in the present study we report the morphological and genetic characteristics of this strain by generating phylogenetic trees on the basis of the sequences of LSU rDNA. Furthermore, we investigated the potential toxicity of the Korean strain of $G$. aureolum by performing a bioassay using the larvae of the brine shrimp Artemia salina. We investigated the ability of G. aureolum to feed on a diverse array of algal species and used high resolution video microscopy and transmission electron microscopy (TEM) to observe feeding behavior and determine the mechanism of prey ingestion. We also measured growth and ingestion rates for G. aureolum feeding on 6 algal species at a single prey concentration. In addition, growth and ingestion rates for $G$. aureolum feeding on the optimal algal species, the cryptophyte Teleaulax sp., were determined as a function of prey concentration.
In addition, we estimated the grazing coefficients attributable to $G$. aureolum on cryptophytes using the ingestion rate data obtained from the laboratory experiments and the abundances of predators and prey in the field. The results of the present study provide a basis for understanding the feeding mechanism and ecological roles of $G$. aureolum in marine planktonic food webs.

\section{MATERIALS AND METHODS}

Preparation of experimental organisms. Phytoplankton species were grown at $20^{\circ} \mathrm{C}$ in enriched $\mathrm{f} / 2$ seawater media (Guillard \& Ryther 1962) under a continuous illumination of $20 \mu \mathrm{E} \mathrm{m} \mathrm{m}^{-2} \mathrm{~s}^{-1}$ provided by cool white fluorescent lights (Table 1$)$. The mean $( \pm \mathrm{SD})$ equivalent spherical diameter (ESD) was measured by an electronic particle counter (Coulter Multisizer II). The carbon content of phytoplankton was estimated from cell volume according to Strathmann (1967).

Gymnodinium aureolum (GenBank accession no. FN392226) was isolated from plankton samples collected from waters off of Saemankeum, Korea, in March 2008 when the water temperature and salinity were $10.0^{\circ} \mathrm{C}$ and 30.5 , respectively. The samples were screened gently through a $154 \mu \mathrm{m}$ Nitex mesh and placed in 6 well tissue culture plates. A clonal culture of G. aureolum was established by 2 serial single cell isolations. As the concentration of G. aureolum increased, G. aureolum was subsequently transferred to 32,270 , and $500 \mathrm{ml}$ polycarbonate (PC) bottles containing fresh $\mathrm{f} / 2$ seawater media. The bottles were again filled to capacity with freshly filtered seawater, capped, and placed on a shelf at $20^{\circ} \mathrm{C}$ under $20 \mu \mathrm{E} \mathrm{m}{ }^{-2}$ $\mathrm{s}^{-1}$ illumination provided by cool white fluorescent lights under a 14:10 h light:dark cycle. The ESD of $G$. aureolum was $19.4 \mu \mathrm{m}$ and its carbon content per cell was $0.44 \mathrm{ng} \mathrm{C}$.

Morphology of Gymnodinium aureolum. The morphology of live cells and those preserved in $4 \%(\mathrm{v} / \mathrm{v})$ glutaraldehyde were examined using an epifluorescence microscope (Axiovert 200M, Zeiss). For scanning electron microscopy (SEM), a $20 \mathrm{ml}$ aliquot of a dense culture of $G$. aureolum was fixed in osmium tetroxide (final concentration $=2 \% \mathrm{w} / \mathrm{v}$ ) in seawater for $1.5 \mathrm{~h}$. The fixed cells were collected on a PC membrane filter (pore size $=5 \mu \mathrm{m}$ ), without applying additional pressure and rinsed 3 times with distilled water to remove the salt. The sample was dehydrated in an ethanol series $(10,30,50,70,90$, and $100 \%$ ethanol, followed by two $100 \%$ ethanol steps) and dried using a critical point dryer (BAL-TEC, CPD 300, Balzers). The dried filters were mounted on a stub and coated with goldpalladium. Cells were viewed using a field emission- 
Table 1. Taxa, sizes, and concentration of prey species offered as food to Gymnodinium aureolum in Expt 1. To confirm no ingestion by the predators on some prey species, additional higher prey concentrations were provided. Mean $( \pm \mathrm{SD})$ equivalent spherical diameter $(\mathrm{ESD})$ for algae and bacteria were measured by an electronic particle counter (Coulter Multisizer II) and under an epifluorescence microscope, respectively ( $n>2000$ for each algal species and $n>30$ for each bacterium). Predator abundances for each target prey were 2000 to 5000 cells ml ${ }^{-1}$. T: thecate; NT: non-thecate; Y/N: G. aureolum was observed/not observed to feed on a living food cell

\begin{tabular}{|c|c|c|c|}
\hline Species & $\begin{array}{l}\mathrm{ESD} \\
(\mu \mathrm{m})\end{array}$ & $\begin{array}{l}\text { Initial prey } \\
\text { concentration } \\
\left(\text { cells ml }{ }^{-1}\right)\end{array}$ & $\begin{array}{l}\text { Feeding by } \\
\text { G. aureolum }\end{array}$ \\
\hline \multicolumn{4}{|l|}{ Bacteria } \\
\hline Heterotrophic bacteria & $0.9 \pm 0.3$ & 7000000 & $\mathrm{Y}$ \\
\hline Synechococcus sp. & $1.0 \pm 0.2$ & 7000000 & $\mathrm{Y}$ \\
\hline \multicolumn{4}{|l|}{ Diatoms } \\
\hline Skeletonema costatum & $5.9 \pm 1.1$ & 150000 & $\mathrm{~N}$ \\
\hline $\begin{array}{l}\text { Prymnesiophyceae } \\
\text { Isochrysis galbana }\end{array}$ & $4.8 \pm 0.2$ & 150000 & $\mathrm{Y}$ \\
\hline \multicolumn{4}{|l|}{ Cryptophytes } \\
\hline Teleaulex sp. & $5.6 \pm 1.5$ & 100000 & $\mathrm{Y}$ \\
\hline Rhodomonas salina & $8.8 \pm 1.5$ & 50000 & $\mathrm{Y}$ \\
\hline $\begin{array}{l}\text { Rhaphidophytes } \\
\text { Heterosigma akashiwo }\end{array}$ & $11.5 \pm 1.9$ & 300000 & $\mathrm{Y}$ \\
\hline \multicolumn{4}{|l|}{ Mixotrophic dinoflagellates } \\
\hline Heterocapsa rotundata $(\mathrm{T})$ & $5.8 \pm 0.4$ & 100000 & $\mathrm{Y}$ \\
\hline Amphidinium carterae (NT) & $9.7 \pm 1.6$ & 30000 & $\mathrm{Y}$ \\
\hline Prorocentrum minimum $(\mathrm{T})$ & $12.1 \pm 2.5$ & $15000-20000$ & $\mathrm{~N}$ \\
\hline Heterocapsa triquetra $(\mathrm{T})$ & $15.0 \pm 4.3$ & $15000-20000$ & $\mathrm{~N}$ \\
\hline Scrippsiella trochoidea $(\mathrm{T})$ & $22.8 \pm 2.7$ & $10000-20000$ & $\mathrm{~N}$ \\
\hline Cochlodinium polykrikoides (NT) & $25.9 \pm 2.9$ & $1000-3000$ & $\mathrm{~N}$ \\
\hline Prorocentrum micans $(\mathrm{T})$ & $26.6 \pm 2.8$ & $1000-3000$ & $\mathrm{~N}$ \\
\hline Akashiwo sanguinea (NT) & $30.8 \pm 3.5$ & $1000-3000$ & $\mathrm{~N}$ \\
\hline Gonyaulax polygramma $(\mathrm{T})$ & $32.5 \pm 5.4$ & $1500-3000$ & $\mathrm{~N}$ \\
\hline Alexandrium tamarense $(\mathrm{T})$ & $32.6 \pm 2.7$ & $1000-3000$ & $\mathrm{~N}$ \\
\hline Lingulodinium polyedrum (T) & $38.2 \pm 3.6$ & $1000-3000$ & $\mathrm{~N}$ \\
\hline
\end{tabular}

followed by two $100 \%$ ethanol steps). The material was embedded in Spurr's low-viscosity resin (Spurr 1969), sectioned using an RMC MT-XL ultramicrotome (Boeckeler Instruments), and stained with $3 \%(\mathrm{w} / \mathrm{v})$ aqueous uranyl acetate followed by lead citrate. The sections were observed using with a JEOL 1010 transmission electron microscope (JEOL).

DNA extraction, PCR amplification, sequencing, and data analysis. Approximately $20 \mathrm{ml}$ of a dense culture of Gymnodinium aureolum was concentrated by centrifugation $(1610 \times g)$ for 5 to $10 \mathrm{~min}$ at room temperature, and the pellet was transferred to a $1.5 \mathrm{ml}$ tube and resuspended in Tris-ethylenediaminetetraacetate (TE) buffer. Sodium dodecyl sulfate (final conc. $=0.5 \%$ $\mathrm{w} / \mathrm{v}$ ) and proteinase $\mathrm{K}$ (final conc. = $0.1 \mathrm{mg} \mathrm{ml}^{-1}$ ) were then added, and the mixture was incubated at $37^{\circ} \mathrm{C}$ for $1 \mathrm{~h}$. DNA was extracted by adding $800 \mu \mathrm{l}$ of phenol:chloroform: isoamyl alcohol $(25: 24: 1)$ to the incubated material and the residual phenol was removed by adding $700 \mu \mathrm{l}$ of chloroform:isoamyl alcohol (24:1). Extracted DNA was precipitated by adding isopropyl alcohol and washed in cold $70 \%$ ethanol. DNA yield was quantified by a spectrophotometer (ND-1000, NanoDrop Technologies). The extracted DNA was divided into 2 PCR tubes, and 2 inde-

scanning electron microscope (FE-SEM) (S-4800+EDS, Horiba; EX-250, Hitachi) and SEM (JSM-840A SEM, JEOL) and photographed using a digital camera (AxioCam HRc5, Zeiss). The length and width of live cells fed either Teleaulax sp. (previously an unidentified cryptophyte in Jeong et al. 2004, 2005c,d) or starved for $2 \mathrm{~d}$ were measured using the digital camera.

For TEM, cells from a dense culture were transferred to a $50 \mathrm{ml}$ tube and fixed in $2.5 \%(\mathrm{v} / \mathrm{v})$ glutaraldehyde in culture medium. After 1.5 to $2 \mathrm{~h}$, the entire contents of the tube were placed in a $50 \mathrm{ml}$ centrifuge tube and concentrated at $1610 \times g$ for $10 \mathrm{~min}$ in a Vision Centrifuge (VS-5500, Vision Scientific). A pellet from the tube was then transferred to a $1.5 \mathrm{ml}$ tube and rinsed in $0.2 \mathrm{M}$ sodium cacodylate at $\mathrm{pH}$ 7.4. After several rinses in the medium, the cells were post-fixed in $1 \%(\mathrm{w} / \mathrm{v})$ osmium tetroxide in deionized water. The pellet was then embedded in $1 \%$ agar (w/v). Subsequently, the dehydrated pellet was accomplished using a graded ethanol series $(50,60,70,80,90$, and $100 \%$ ethanol, pendent PCR reactions were performed. SSU rDNA was amplified using eukaryotic primers (forward: 5'AAC CTG GTT GAT CCT GCC AGT-3'; reverse: 5'TGA TCC TTC TGC AGG TTC ACC TAC-3') and LSU rDNA was amplified using forward primer Dino 1500F (5'-GTT GTT GCG GTT AAA AAG C-3') and reverse primer LSUB (5'-ACG AAC GAT TTG CAC GTC AG$3^{\prime}$ ), following Medlin et al. (1988). A $50 \mu \mathrm{l}$ PCR was mixed with the following reactants: $1 \times$ PCR buffer with $1.5 \mathrm{mM} \mathrm{MgCl}_{2}, 0.2 \mathrm{mM}$ dNTP, $0.5 \mu \mathrm{M}$ of each primer, $5 \mathrm{U}$ of Taq DNA polymerase (Bioneer), and $200 \mathrm{ng}$ template DNA. PCRs were performed under the following conditions: 1 initial cycle of $3 \mathrm{~min}$ at $94^{\circ} \mathrm{C}$, 40 cycles of $45 \mathrm{~s}$ at $95^{\circ} \mathrm{C}, 1 \mathrm{~min}$ at $55^{\circ} \mathrm{C}, 3 \mathrm{~min}$ at $72^{\circ} \mathrm{C}$ in series, and then 1 extension cycle at $72^{\circ} \mathrm{C}$ for $5 \mathrm{~min}$ in a GeneAmp PCR System 2700 (Perkin-Elmer). PCR products were cloned into the $\mathrm{pCR}^{\circledR}{ }^{\circledR}$.1-TOPO ${ }^{\circledR}$ vector using the TA Cloning ${ }^{\circledR}$ kit (Invitrogen). The cloned material was incubated in liquid Luria-Bertani (LB) media at $37^{\circ} \mathrm{C}$ overnight. Plasmids were extracted 
using the AccuPrep ${ }^{\circledR}$ Plasmid Extraction kit (Bioneer). The presence of inserts in the plasmids was ascertained by adding ECoRI restriction endonuclease (Promega) sites into the extracted plasmids. To determine the sequence of the fragments within the inserts, the reverse primers Euk1209R (5'-GGG CAT CAC AGA CCT G-3') and ITSR2 (5'-TCC CTG TTC ATT CGC CAT TA-3') were used. SSU rDNA and LSU rDNA sequencing was performed using an ABI PRISM ${ }^{\circledR} 3700$ DNA Analyzer (Applied Biosystems). All the sequences were aligned using the ContigExpress alignment program (InforMax).

Sequence availability and phylogenetic analysis. The sequence for the nuclear LSU rDNA was aligned manually in the Genetic Data Environment (GDE 2.2) program. For Bayesian analyses, we performed a likelihood ratio test using MODELTEST 3.7 (Posada \& Crandall 1998) to determine the best available model for the LSU rDNA data (Table 2). The selected models were a $\operatorname{TrN}+\mathrm{I}+\Gamma$ model with a gamma correction for among-site rate variation $(\gamma=0.7138)$ and an invariant site model $(\mathrm{I}=0.3033)$. Bayesian analyses were run using an MrBayes 3.1.1 version (Huelsenbeck \& Ronquist 2001). Four independent Markov chain Monte Carlo simulations were run simultaneously for 2000000 generations, and trees were sampled every 1000 generations; the first 800 trees were deleted to ensure that the likelihood had reached convergence. A consensus tree with $50 \%$ majority rule of the 1200 trees was obtained, while constructing trees thereby resulting in uniform Bayesian posterior probabilities (BPP) across all data sets.

Maximum likelihood phylogenetic analyses were performed using the RAxML 7.0.3 program (Stamatakis 2006) with the general time reversible (GTR) + $\Gamma$ model. The \# option of the program was used to identify the best tree from among 200 independent tree inferences. Bootstrap values were calculated using 1000 replicates using the same substitution model.

Toxicity. To investigate potential toxicity of the Korean Gymnodinium aureolum strain, we conducted a bioassay using larvae of the brine shrimp Artemia salina.

Encysted eggs of Artemia salina were hatched in $500 \mathrm{ml}$ of natural seawater under artificial light at $20^{\circ} \mathrm{C}$ for $48 \mathrm{~h}$. Ten A. salina nauplii were placed in each well of a 6 well plate containing a Gymnodinium aureolum culture. Two densities of $G$. aureolum were tested, and initial concentrations were 4940 and 15180 cells ml$^{-1}$. Triplicate experimental wells for each prey concentration (nauplii plus G. aureolum), triplicate nauplii control wells (nauplii only, without prey), and triplicate prey control wells were established. Experimental treatments were incubated at $20^{\circ} \mathrm{C}$ under a $14: 10 \mathrm{~h}$ light:dark cycle of cool white fluorescent light at $20 \mu \mathrm{E}$ $\mathrm{m}^{-2} \mathrm{~s}^{-1}$. At the beginning and after $6,12,24$, and $48 \mathrm{~h}$
Table 2. Species used in constructing phylogenetic trees and their GenBank accession numbers

\begin{tabular}{|c|c|}
\hline Taxon & $\begin{array}{c}\text { LSU rDNA } \\
\text { Accession no. (strain) }\end{array}$ \\
\hline Akashiwo sanguinea & AF260397 \\
\hline Akashiwo sanguinea & DQ156229 \\
\hline Gymnodinium aureolum & DQ917486 \\
\hline Gymnodinium aureolum & AF200670 \\
\hline Gymnodinium aureolum & AF200671 \\
\hline Gymnodinium aureolum & AY263965 \\
\hline Gymnodinium aureolum & AY464687 \\
\hline Gymnodinium aureolum & AY947659 \\
\hline Gymnodinium aureolum & AY947660 \\
\hline Gymnodinium aureolum & AY947661 \\
\hline Gymnodinium aureolum & FN392226 \\
\hline Gymnodinium beii & DQ198075 \\
\hline Gymnodinium catenatum & AF200672 \\
\hline Gymnodinium chlorophorum & AF200669 \\
\hline Gymnodinium falcatum & AY320049 \\
\hline Gymnodinium fuscum & AF200676 \\
\hline Gymnodinium impudicum & AF200674 \\
\hline Gymnodinium microreticulatum & AY036078 \\
\hline Gymnodinium palustre & AF260382 \\
\hline Gymnodinium venator & AY455681 \\
\hline Gyrodinium dominans & AY571370 \\
\hline Gyrodinium instriatum & DQ084521 \\
\hline Gyrodinium spirale & AY571371 \\
\hline Gyrodinium uncatenum & AY916541 \\
\hline Karenia brevis & AF200677 \\
\hline Karenia mikimotoi & AF200678 \\
\hline Karenia mikimotoi & AF200679 \\
\hline Karenia mikimotoi & AF200680 \\
\hline Karenia mikimotoi & AF200681 \\
\hline Karenia mikimotoi & AF200682 \\
\hline Karenia mikimotoi & U92247 \\
\hline Karenia mikimotoi & U92249 \\
\hline Karenia selliformis & U92250 \\
\hline Karlodinium armiger & DQ114467 \\
\hline Karlodinium australe & DQ151559 \\
\hline Karlodinium veneficum & AY263964 \\
\hline Lepidodinium chlorophorum & AF200669 \\
\hline Polykrikos kofoidii & EF192411 \\
\hline Polykrikos schwartzii & EF192408 \\
\hline Prorocentrum donghaiense & AY822610 \\
\hline Takayama helix & AY284950 \\
\hline Takayama pulchella & U92254 \\
\hline Takayama tasmanica & AY284948 \\
\hline Woloszynskia tenuissima & AY571374 \\
\hline
\end{tabular}

incubation, living and dead nauplii were counted under a dissecting microscope (SZX12, Olympus) at a magnification of 7 to $40 \times$.

Expt 1: Prey species. Expt 1 was designed to investigate whether or not Gymnodinium aureolum was able to feed on heterotrophic bacteria, and a variety of microalgal species (Table 1). The initial concentrations of each algal species provided were similar in terms of carbon biomass. To confirm whether some of the algal species were not ingested by G. aureolum, we provided additional higher prey concentrations. 
A dense culture of Gymnodinium aureolum growing photosynthetically in f/2 media under a 14:10 h light:dark cycle at $20 \mu \mathrm{E} \mathrm{m} \mathrm{m}^{-2} \mathrm{~s}^{-1}$ was transferred to one $11 \mathrm{PC}$ bottle containing f/2 medium. The culture was maintained in $\mathrm{f} / 2$ media for $2 \mathrm{~d}$ under the same conditions described above. Three $1 \mathrm{ml}$ aliquots were then removed from the bottle and G. aureolum densities were determined with a compound light microscope.

For observation of heterotrophic bacterial prey, $1 \mathrm{~d}$ prior to Expt 1, the bacterial cells that originated from a non-axenic culture of Gymnodinium aureolum were fluorescently labeled using the methods described by Sherr et al. (1987). The fluorescently labeled bacteria (FLB) were added to each of the three $80 \mathrm{ml}$ PC bottles (final conc. $=$ ca. $7 \times 10^{6}$ cells $\mathrm{ml}^{-1}$ ); each bottle contained an initial G. aureolum concentration of 2000 cells $\mathrm{ml}^{-1}$. Triplicate $80 \mathrm{ml}$ PC experimental bottles (containing mixtures of predator and prey) and triplicate predator control bottles (predators only) were also established. The bottles were filled to capacity with freshly filtered seawater, capped, placed on a vertically rotating plate rotating at $0.9 \mathrm{rpm}$, and incubated at $20^{\circ} \mathrm{C}$ at a light intensity of $20 \mu \mathrm{E} \mathrm{m}^{-2} \mathrm{~s}^{-1}$. After 5, 10, 30 , and $60 \mathrm{~min}$ and $4 \mathrm{~h}$, a $5 \mathrm{ml}$ aliquot was removed from each bottle and fixed in formalin (final conc. = $3 \%$ ). The fixed samples were stained with DAPI (final conc. $=1 \mu \mathrm{M}$ ) and filtered onto $5 \mu \mathrm{m}$ pore-sized PC black membrane filters. Ingested FLB inside G. aureolum cells were observed under an epifluorescence microscope (Axiovert 200M, Zeiss) with blue light excitation at a magnification of $1000 x_{i}$ G. aureolum cells containing ingested FLB cells were photographed using a digital camera (AxioCam MRc5, Zeiss).

When Synechococcus sp. was used as the prey, the initial concentrations of Gymnodinium aureolum (ca. 2000 cells ml ${ }^{-1}$ ) and Synechococcus sp. (ca. $7 \times 10^{6}$ cells $\mathrm{ml}^{-1}$ ) were established using an autopipette to deliver a predetermined volume of culture with a known cell density to the experimental bottles. Triplicate $80 \mathrm{ml}$ PC experimental bottles and triplicate predator control bottles were set up at a single prey concentration. The bottles were incubated and a $5 \mathrm{ml}$ aliquot was removed from each bottle and fixed at the intervals described in the previous paragraph. The fixed aliquots were filtered onto $5 \mu \mathrm{m}$ pore-sized, $25 \mathrm{~mm}$ PC black membrane filters, and the concentrated cells on the membranes were then observed under the epifluorescence microscope with green light excitation at a magnification of $1000 \times$ to determine whether or not the predator was able to feed on Synechococcus sp. G. aureolum cells containing ingested Synechococcus sp. cells were photographed using the digital camera on the microscope with green light excitation at a magnification of $1000 \times$.
To observe the ingestion of eukaryotic algal prey under a light microscope and/or an epifluorescence microscope, the initial concentrations of Gymnodinium aureolum and each target algal species were established as described in the previous paragraph. Triplicate $80 \mathrm{ml}$ PC experimental bottles and duplicate predator control bottles were set up for each target algal species. The bottles were filled to capacity with freshly filtered seawater, capped, placed on a vertically rotating plate rotating at $0.9 \mathrm{rpm}$, and incubated at $20^{\circ} \mathrm{C}$ under a $14: 10 \mathrm{~h}$ light:dark cycle of cool white fluorescent light at $20 \mu \mathrm{E} \mathrm{m} \mathrm{m}^{-2} \mathrm{~s}^{-1}$. After 6, 12, 24, and $48 \mathrm{~h}$ incubation, a $5 \mathrm{ml}$ aliquot was removed from each bottle and transferred into a $20 \mathrm{ml}$ bottle. Two $0.10 \mathrm{ml}$ aliquots were placed on slides with cover-glasses. Under these conditions, the G. aureolum cells were alive, but almost motionless. The protoplasms of $>200$ G. aureolum cells were carefully examined using a light microscope and/or the epifluorescence microscope at a magnification of 100 to $400 \times$ to determine whether $G$. aureolum was able to feed on the target algal prey species; $G$. aureolum cells containing the ingested cells of each target algal species were photographed using digital cameras on these microscopes at a magnification of 400 to $1000 \times$.

Ingestion of eukaryotic algal prey also was examined using TEM. Approximately $8.1 \times 10^{6}$ to $2.7 \times 10^{7}$ cells of each target algal species (Isochrysis galbana, Teleaulax sp. [previously an unidentified cryptophyte in Jeong et al. 2004, 2005c,d], Heterocapsa rotundata, Rhodomonas salina, Heterosigma akashiwo, and Amphidinium carterae) were added to each of three $270 \mathrm{ml}$ PC bottles (final conc. $=30000$ to 100000 cells $\mathrm{ml}^{-1}$ ); each contained Gymnodinium aureolum at a concentration of 2000 to 5000 cells ml ${ }^{-1}$. One target prey only' control bottle and one G. aureolum control bottle (without added prey) were also set up for each experiment. The bottles were placed on a vertically rotating plate rotating at $0.9 \mathrm{rpm}$ and incubated at $20^{\circ} \mathrm{C}$ under a $14: 10 \mathrm{~h}$ light:dark cycle of cool white fluorescent light at $20 \mu \mathrm{E} \mathrm{m} \mathrm{m}^{-2} \mathrm{~s}^{-1}$. At the beginning, and after $2 \mathrm{~d}$ incubation periods, the contents of one experimental bottle from each interval were distributed into five $50 \mathrm{ml}$ centrifugal tubes and then concentrated at $1610 \times g$ for $10 \mathrm{~min}$. Five pellets from the 5 centrifugal tubes were then transferred into $1.5 \mathrm{ml}$ tubes and fixed for $1.5 \mathrm{~h}$ in $4 \%(\mathrm{w} / \mathrm{v})$ glutaraldehyde in a culture medium. Next, the fixative was removed and the pellets were rinsed, post-fixed, and embedded as described in 'Morphology and rDNA sequence'. Dehydration was accomplished using a graded ethanol series and the material was embedded as described above. Sections were obtained using the RMC MT-XL ultramicrotome, post-stained, and the stained sections were viewed as described above. 
Expt 2: Feeding mechanism. Expt 2 was designed to investigate the feeding mechanism(s) of Gymnodinium aureolum when provided a unialgal diet of Isochrysis galbana, Teleaulax sp., Heterocapsa rotundata, Rhodomonas salina, Heterosigma akashiwo, and Amphidinium carterae. It was confirmed in Expt 1 that $G$. aureolum fed on these prey species. The initial concentrations of the predator and prey were the same as in Expt 1.

The initial concentrations of Gymnodinium aureolum and the target algal species were established using an autopipette to deliver a predetermined volume of culture with a known cell density to the experimental bottles. One $80 \mathrm{ml}$ PC bottle (mixtures of $G$. aureolum and algal prey) was set up for each target algal species. The bottle was filled to capacity with freshly filtered seawater, capped, and then mixed well. After $1 \mathrm{~min}$ of incubation, a $1 \mathrm{ml}$ aliquot was removed from the bottle and transferred into a Sedgwick-Rafter chamber (SRC). For each target prey species, the feeding behavior of $>60 \mathrm{G}$. aureolum cells was monitored using a light microscope and/or an epifluorescence microscope at a magnification of 100 to $630 \times$. All of the feeding processes were observed from the time a prey cell was captured to the time that it was ingested by the predator. A series of photographs showing the feeding process for a $G$. aureolum cell were taken using a video analyzing system (Sony DXC-C33) mounted on an epifluorescence microscope at a magnification of 100 to 630×. After Teleaulax sp. was provided to $G$. aureolum as prey, the time to be completely ingested by a $G$. aureolum cell after the predator had deployed its peduncle to the prey cell was measured.

Expt 3: Comparison of growth and ingestion rates at a single prey concentration. Expt 3 was designed to compare the growth and ingestion rates of Gymnodinium aureolum when the mixotrophic dinoflagellates Amphidinium carterae and Heterocapsa rotundata, the raphidophyte Heterosigma akashiwo, the cryptophytes Rhodomonas salina and Teleaulax sp., and the prymnesiophyte Isochrysis galbana were provided at a single prey concentration (see Table 3). It was confirmed in Expt 1 that these prey species were consumed by $G$. aureolum.

A dense culture of Gymnodinium aureolum growing photosynthetically under a 14:10 h light:dark cycle at $20 \mu \mathrm{E} \mathrm{m} \mathrm{m}^{-2} \mathrm{~s}^{-1}$ in $\mathrm{f} / 2$ medium was transferred to a $1 \mathrm{l}$ PC bottle. Three $1 \mathrm{ml}$ aliquots from the bottle were counted using a compound microscope to determine the cell concentrations of G. aureolum, and the cultures were then used for further experiments.

The initial concentrations of Gymnodinium aureolum and each target prey were established using an autopipette to deliver predetermined volumes of known cell concentrations to the bottles. Triplicate $42 \mathrm{ml} \mathrm{PC} \mathrm{ex-}$ perimental bottles (containing mixtures of predator and prey), triplicate prey control bottles (prey only), and triplicate predator control bottles (predators only) were set up for each target prey species. To ensure similar experimental conditions, the water from a G. aureolum culture was filtered through a $0.7 \mu \mathrm{m}$ GF/F filter and added to the prey control bottles in the same amount as the volume of the predator culture added to the experiment bottles for each predator-prey combination. Next, $5 \mathrm{ml}$ of $\mathrm{f} / 2$ medium was added to all the bottles, which were then filled to capacity with freshly filtered seawater and capped. To determine the actual predator and prey concentrations at the beginning of the experiment and after $2 \mathrm{~d}$ for the algal prey, a $5 \mathrm{ml}$ aliquot was removed from each bottle and fixed with $5 \%$ Lugol's solution, and all or $>300$ predator and prey cells in three $1 \mathrm{ml}$ SRCs were enumerated. Prior to taking subsamples, the condition of $G$. aureolum and its prey was assessed using a dissecting microscope. The bottles were filled again to capacity with freshly filtered seawater, capped, placed on a rotating wheel at $0.9 \mathrm{rpm}$, and incubated at $20^{\circ} \mathrm{C}$ under a $14: 10 \mathrm{~h}$ light:dark cycle of cool white fluorescent light at $20 \mu \mathrm{E} \mathrm{m} \mathrm{m}^{-2} \mathrm{~s}^{-1}$. The dilution of the cultures associated with refilling the bottles was considered in calculating the growth and ingestion rates.

The specific growth rate of Gymnodinium aureolum, $\mu\left(\mathrm{d}^{-1}\right)$, was calculated as follows:

$$
\mu=\frac{\operatorname{Ln}\left(G_{t} / G_{0}\right)}{t}
$$

where $G_{0}$ is the initial concentration of $G$. aureolum and $G_{t}$ is the final concentration after time $t(t=2 \mathrm{~d})$.

The ingestion and clearance rates were calculated using the equations of Frost (1972) and Heinbokel (1978). The incubation times for calculating the ingestion and clearance rates were the same as those for estimating the growth rate.

Expt 4: Effects of prey concentration. Expt 4 was designed to investigate the effects of prey concentration on the growth and ingestion rate of Gymnodinium aureolum. We measured the growth, ingestion, and clearance rates of $G$. aureolum on Teleaulax sp. (carbon content per cell $=0.017 \mathrm{ng} \mathrm{C}$ ) as a function of prey concentration.

A dense culture of Gymnodinium aureolum growing photosynthetically under a 14:10 h light:dark cycle at $20 \mu \mathrm{E} \mathrm{m} \mathrm{m}^{-2} \mathrm{~s}^{-1}$ in $\mathrm{f} / 2$ medium was transferred into a $1 \mathrm{l}$ PC bottle. Three $1 \mathrm{ml}$ aliquots were counted using a compound microscope to determine the cell concentrations of G. aureolum in each bottle, and the cultures were then used to conduct experiments.

The initial concentrations of Gymnodinium aureolum and Teleaulax sp. were established as described in Expt 3. Triplicate $42 \mathrm{ml} \mathrm{PC}$ experimental bottles 
(containing mixtures of predator and prey), triplicate prey control bottles (prey only), and triplicate predator control bottles (predators only) were set up for each predator-prey combination. To ensure uniform water conditions, we used the same procedure that was used in Expt 3. Next, $5 \mathrm{ml}$ of f/ 2 medium was added to all the bottles, which were then filled to capacity with freshly filtered seawater and capped. To determine the actual initial predator and prey densities (cells $\mathrm{ml}^{-1}$ ) at the beginning of the experiment and after a $2 \mathrm{~d}$ incubation, $5 \mathrm{ml}$ aliquots were removed from each bottle and fixed with $5 \%$ Lugol's solution, and all G. aureolum cells and all or $>300$ prey cells in three $1 \mathrm{ml}$ SRCs were enumerated. Prior to taking subsamples, the condition of $G$. aureolum and its prey was assessed under a dissecting microscope. The bottles were filled again to capacity with f/2 medium, capped, placed on a vertically rotating plate rotating at $0.9 \mathrm{rpm}$, and incubated at $20^{\circ} \mathrm{C}$ under a $14 \mathrm{~h}$ light:10 h dark cycle at $20 \mu \mathrm{E} \mathrm{m} \mathrm{m}^{-2} \mathrm{~s}^{-1}$ of cool white fluorescent light. The light intensity of $20 \mu \mathrm{E}$ $\mathrm{m}^{-2} \mathrm{~s}^{-1}$ was used to enable comparisons of growth and ingestion rates for several other mixotrophic dinoflagellates under the same conditions (summarized by Burkholder et al. 2008). The dilution of the cultures associated with refilling the bottles was taken into consideration in calculating the growth and ingestion rates.

The specific growth rate of Gymnodinium aureolum, $\mu\left(\mathrm{d}^{-1}\right)$, was calculated as described above. Ingestion and clearance rates for $2 \mathrm{~d}$ were calculated using the equations of Frost (1972) and Heinbokel (1978). Ingestion rate data were fitted to a Michaelis-Menten equation as follows:

$$
\mathrm{IR}=\frac{I_{\max } X}{K_{\mathrm{IR}}+X}
$$

where $I_{\max }$ is the maximum ingestion rate (cells predator $^{-1} \mathrm{~d}^{-1}$ or ng $\mathrm{C}$ predator $\left.{ }^{-1} \mathrm{~d}^{-1}\right) ; X$ is the prey concentration (cells ml-1 or ng C ml-1 ${ }^{-1}$, and $K_{\mathrm{IR}}$ is the prey concentration sustaining $1 / 2 I_{\max }$.

Potential grazing impact. By combining field data on the abundances of the predator and the target prey with the ingestion rates of the predator on the prey obtained in the present study, we estimated the grazing coefficients attributable to Gymnodinium aureolum on co-occurring cryptophytes. Data on the abundances of $G$. aureolum and the co-occurring cryptophytes used in this estimate were obtained by analyzing water samples taken from waters off Saemankeum, Korea, in 2006-2008.

The grazing coefficients $\left(g, \mathrm{~d}^{-1}\right)$ were calculated using the following formula:

$$
g=24(\mathrm{CR})(G)
$$

where CR (ml predator ${ }^{-1} \mathrm{~h}^{-1}$ ) is the clearance rate of Gymnodinium aureolum on a target prey species at a given prey concentration and $G$ is the predator concentration (cells $\mathrm{ml}^{-1}$ ). The $\mathrm{CR}$ values were calculated as follows:

$$
\mathrm{CR}=\mathrm{IR} / X
$$

where IR (cells eaten predator ${ }^{-1} \mathrm{~h}^{-1}$ ) is the ingestion rate of $G$. aureolum on the target prey and $X$ (cells $\mathrm{ml}^{-1}$ ) is the prey concentration. These CR values were corrected using $\mathrm{Q}_{10}=2.8$ (Hansen et al. 1997) because the in situ water temperature and the temperature used in the laboratory for this experiment $\left(20^{\circ} \mathrm{C}\right)$ were sometimes different.

Swimming speed. A dense culture (ca. 15000 cells $\mathrm{ml}^{-1}$ ) of Gymnodinium aureolum growing photosynthetically under a 14:10 h light:dark cycle at $20 \mu \mathrm{E} \mathrm{m} \mathrm{m}^{-2}$ $\mathrm{s}^{-1}$ in $\mathrm{f} / 2$ medium was transferred into a $500 \mathrm{ml} \mathrm{PC}$ bottle. An aliquot from the bottle was added to a $50 \mathrm{ml}$ cell culture flask and allowed to acclimate for $30 \mathrm{~min}$. The video camera was focused on a field (i.e. observed as 1 circle) in a cell culture flask under a dissecting microscope at $20^{\circ} \mathrm{C}$ and swimming G. aureolum cells were recorded at a magnification of $50 \times$ using a video analyzing system (SV-C660, Samsung) and captured using a CCD camera (KP-D20BU, Hitachi). The mean and maximum swimming velocities were analyzed for all swimming cells observed in the first $10 \mathrm{~min}$. The average swimming speed was calculated on the basis of the linear displacement of cells in $1 \mathrm{~s}$ during singleframe playback. The swimming speeds of 30 cells were measured.

Statistical analyses. To determine whether the mean of cell length or width of live cells growing photosynthetically was significantly greater than that of live cells feeding on Teleaulax sp., a $t$-test was performed. In addition, a $t$-test was used to determine whether the growth rate (mixotrophic growth) of Gymnodinium aureolum on algal prey was significantly different from that without added prey (autotrophic growth) at the same conditions.

ANOVA was used to determine if there were differences in the growth and ingestion rates of Gymnodinium aureolum on 6 edible prey species at a single prey concentration. In addition, a linear regression was used to test whether the growth and ingestion rates of Gymnodinium aureolum on the 6 edible prey species were significantly correlated with prey size.

\section{RESULTS}

\section{Morphology and rDNA sequence}

The epicone of this Korean strain of Gymnodinium aureolum is somewhat conical and slightly smaller than the hemispherical hypocone (Fig. 1A,B). This 

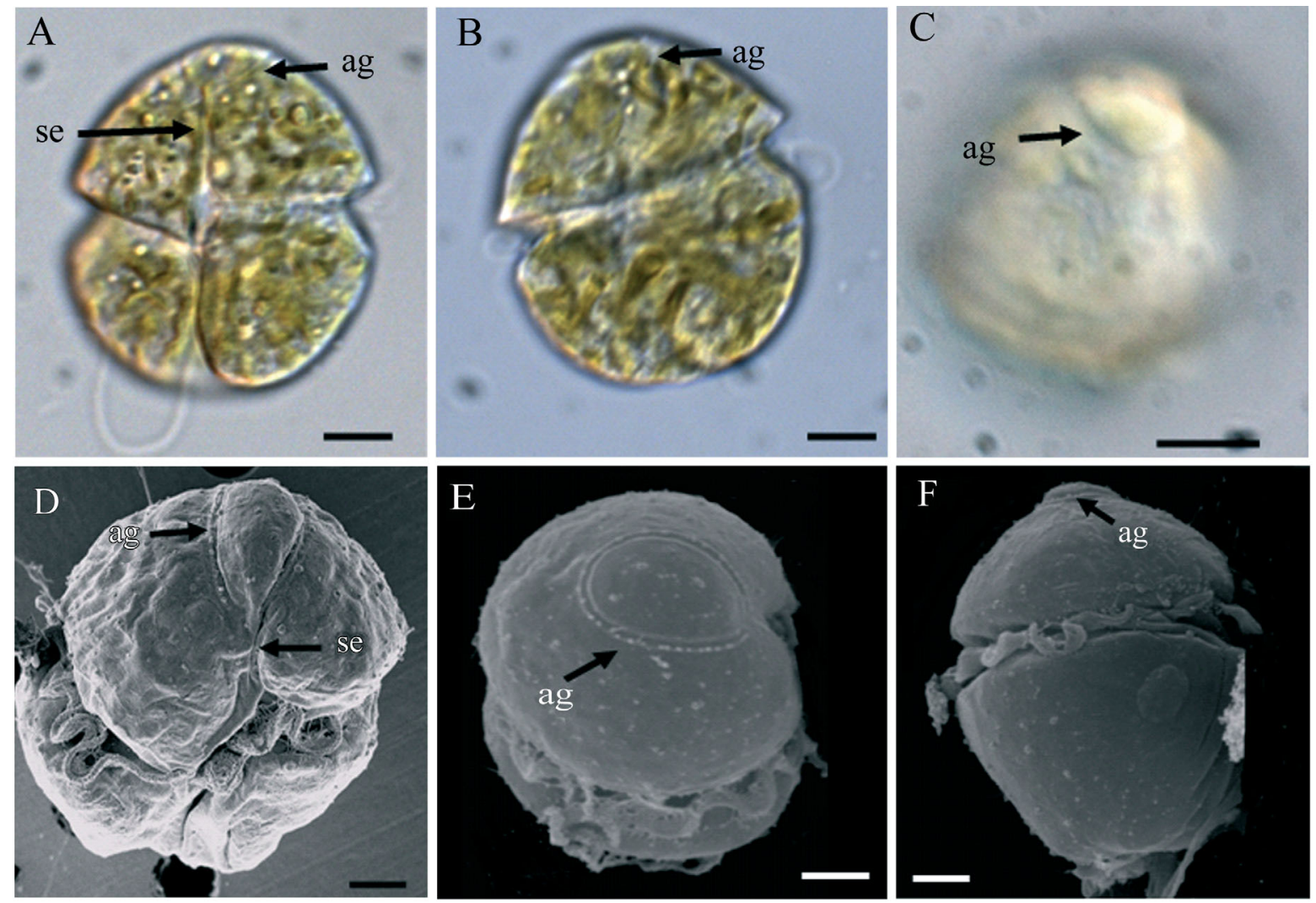

Fig. 1. Gymnodinium aureolum. Micrographs of G. aureolum isolated from coastal waters off Saemankeum, Korea, using (A-C) light microscopy and (D-F) scanning electron microscopy. (A) Ventral view; (B, F) dorsal view; (C-E) apical view. ag: apical groove; se: sulcal extension. Scale bars $=(A-C) 5 \mu \mathrm{m}$ and $(D-F) 2 \mu \mathrm{m}$

G. aureolum had a horseshoe-shaped apical groove on the epicone (Fig. 1C-F). In addition, there was a distinctive sulcul extension invading the epicone (Fig. 1A,D). The cingulum of this dinoflagellate was 0.16 to 0.26 times the cell length and was displaced by 0.25 to 0.33 times the cell length (Fig. 1). The mean $( \pm \mathrm{SE}$, range, $\mathrm{n})$ cell length of live cells growing photosynthetically $(21.3 \pm 0.5 \mu \mathrm{m}, 18.0$ to $28.4 \mu \mathrm{m}, 32)$ was significantly greater than that of live cells feeding on Teleaulax sp. $(19.8 \pm 0.6 \mu \mathrm{m}, 14.7$ to $27.9 \mu \mathrm{m}, 32 ; 1$ tailed $t$-test, $\mathrm{p}<0.01)$, while the mean cell width of live cells growing photosynthetically $(15.2 \pm 0.5 \mu \mathrm{m}, 11.6$ to $21.2 \mu \mathrm{m}, 32)$ was not significantly greater than that of live cells feeding on Teleaulax sp. $(15.6 \pm 0.6 \mu \mathrm{m}, 11.9$ to $22.9 \mu \mathrm{m}, 3$; 1 -tailed $t$-test, $\mathrm{p}>0.1$ ).

The sequence of SSU, ITS1 and 2, 5.8S, and LSU rDNA (total of $3300 \mathrm{bp}$ ) of this Korean strain of Gymnodinium aureolum was very similar (difference of $5 \mathrm{bp}$ ) to that of a strain of $G$. aureolum isolated from the Benguela Current waters off Namibia (GenBank accession no. AY999082). The LSU rDNA of this dinoflagellate was the same as a $G$. aureolum isolate from a tributary of Chesapeake Bay, USA (DQ917486) and very similar (difference of 1 to $3 \mathrm{bp}$ ) to that of $G$. aureolum isolated from Denmark (AF200671), Australia (AY263695), New Zealand (AY947659, AY947660, and AY947661), South Africa (AY464687), and the Pettaquamscutt River, USA (AF200670). The phylogenetic trees based on the sequences of LSU rDNA of dinoflagellates show that this dinoflagellate belongs to the G. aureolum clade and is distant from the Karenia mikimotoi clade (Fig. 2). Based on morphological and molecular analyses, this dinoflagellate is G. aureolum.

\section{Toxicity}

None of the nauplii of Artemia salina at the Gymnodinium aureolum concentrations of 4940 and 15180 cells $\mathrm{ml}^{-1}$ died after $48 \mathrm{~h}$ incubation.

\section{Expt 1: prey species}

Among the diverse prey provided, Gymnodinium aureolum ingested heterotrophic bacteria, cyanobacteria (Fig. 3A,B), and algal species that had ESDs $\leq 11.5 \mu \mathrm{m}$ (e.g. Isochrysis galbana, Teleaulax sp., 


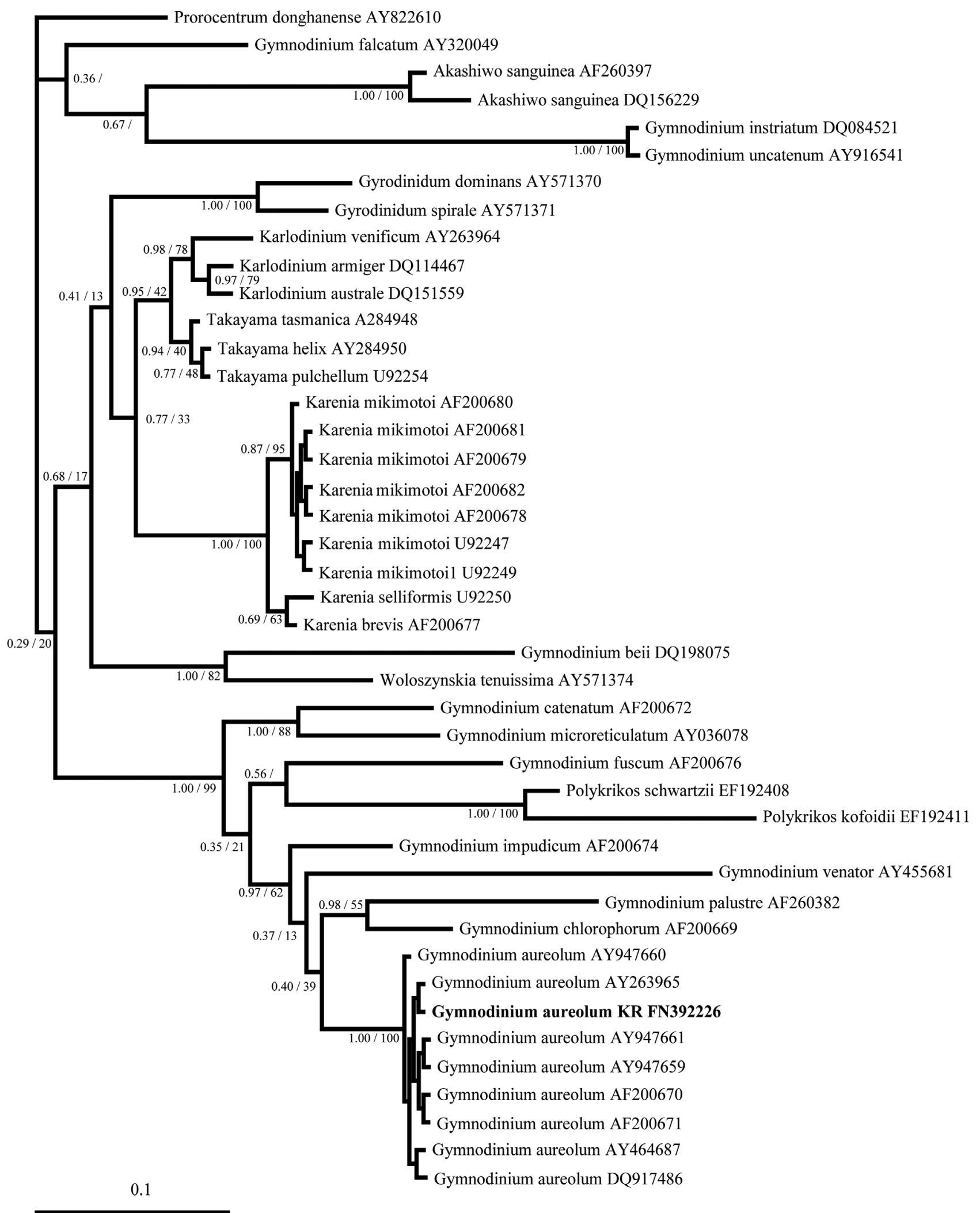

Fig. 2. Bayesian consensus trees based on LSU rDNA data from 582 aligned positions of the LSU rDNA for dinoflagellates. Numbers next to the branches indicate the Bayesian posterior probability (left) and maximum likelihood bootstrap values (right) 

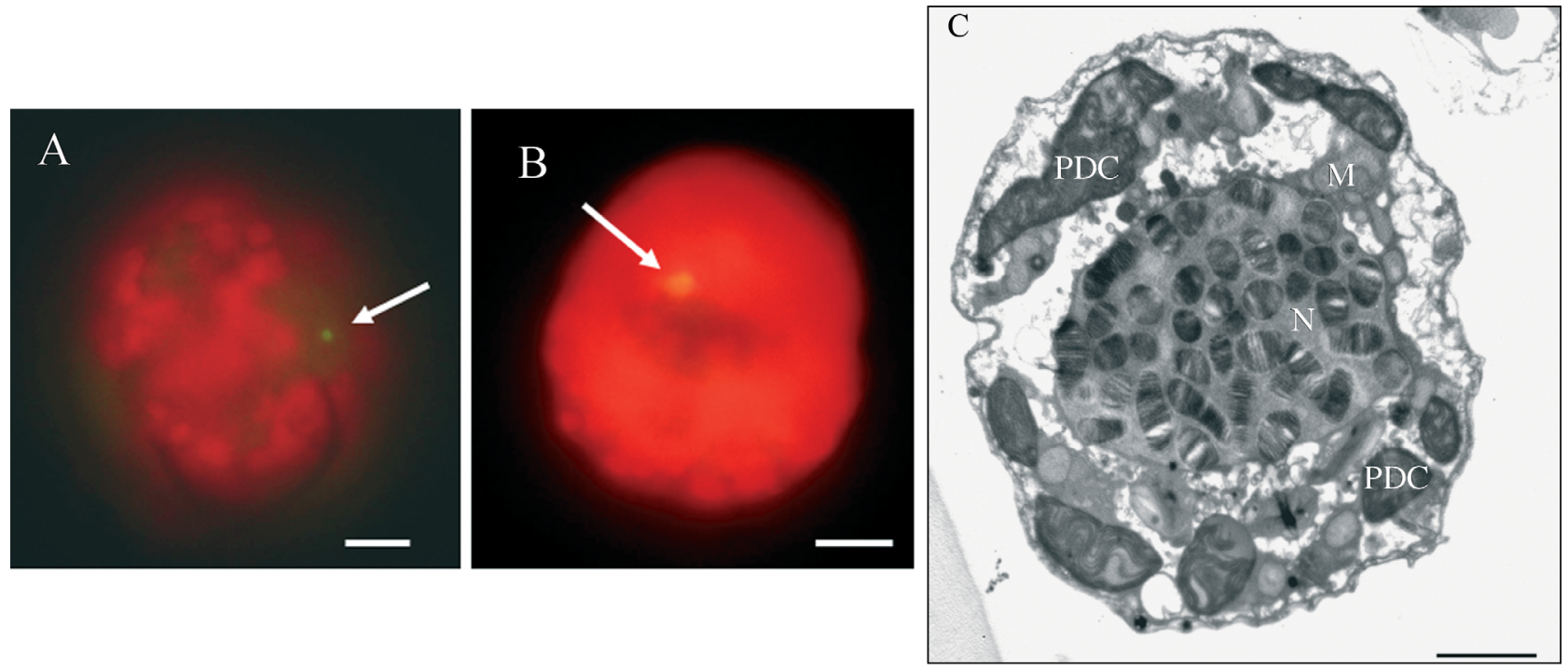
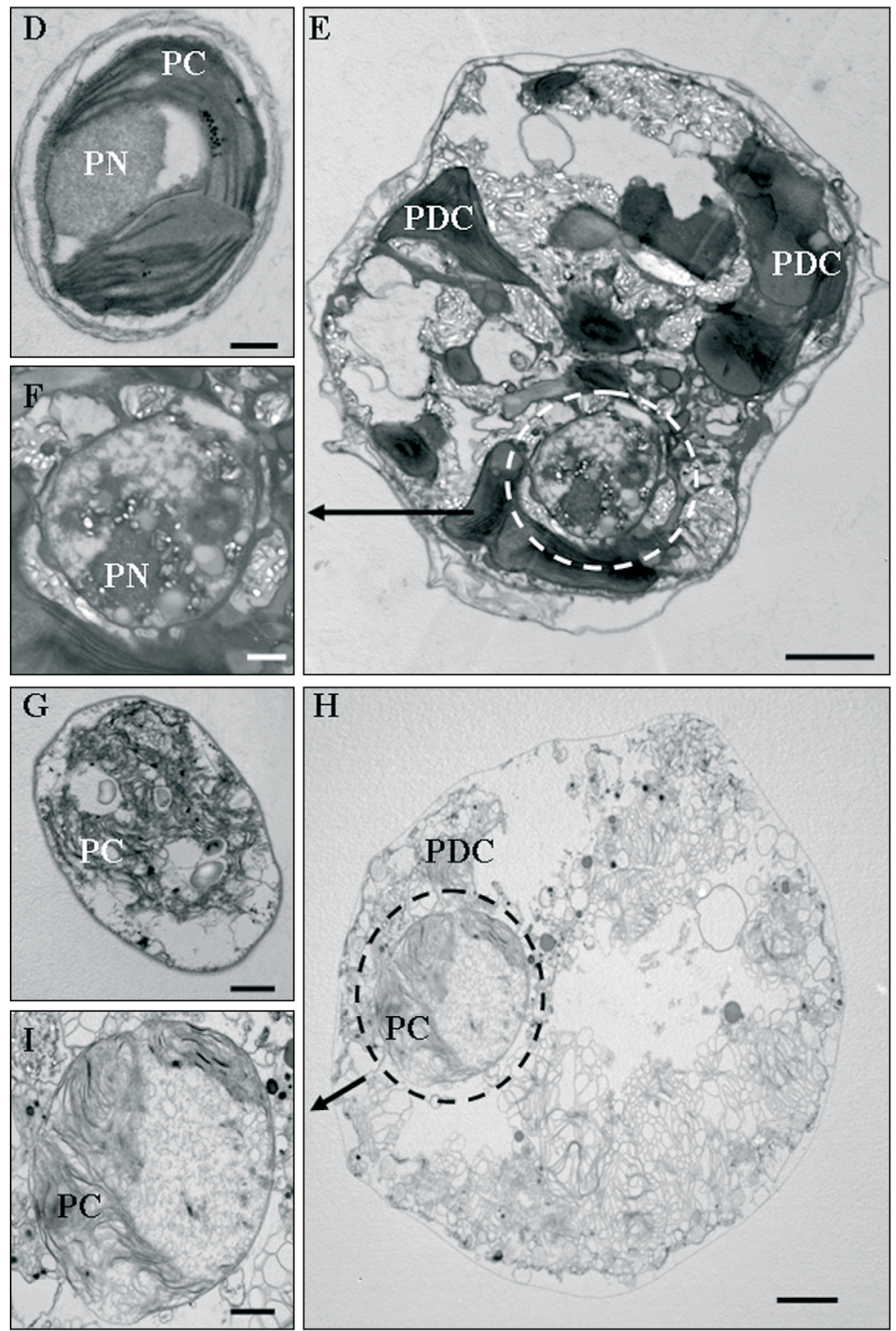

Fig. 3. Gymnodinium aureolum. Feeding by $G$. aureolum on diverse prey species. (A) G. aureolum cell with an ingested fluorescently labeled heterotrophic bacterium (bright green inclusion, white arrow). (B) G. aureolum cell with an ingested Synechococcus sp. cell (orange inclusions, white arrow). (C) Unfed G. aureolum cell. (D) Isochrysis galbana cell not ingested. (E) G. aureolum cell with an ingested I. galbana cell. (F) Enlarged from (E). (G) Amphidinium carterae cell not ingested. (H) G. aureolum cell with an ingested A. carterae cell. (I) Enlarged from (H). Photomicrographs in (A) and (B) were taken using an epifluorescence microscope, while those in $(\mathrm{C}-\mathrm{I})$ were taken with a transmission electron microscope. $\mathrm{M}$ : mitochondria; $\mathrm{N}$ : nucleus; PC: prey chloroplast; PDC: predator chloroplast; $\mathrm{PN}$ : prey nucleus. Scale bars $=(A, B) 5.0 \mu m ;(C, E, H)$ $2.0 \mu \mathrm{m} ;$ and $(\mathrm{D}, \mathrm{F}, \mathrm{G}, \mathrm{I}) 0.5 \mu \mathrm{m}$

Rhodomonas salina, Heterosigma akashiwo, Heterocapsa rotundata, and Amphidinium carterae), except the diatom Skeletonema costatum (Table 1). TEM photographs, taken before and after edible algal prey was provided, clearly showed that $G$. aureolum contained ingested algal prey cells inside its protoplasm (Fig. 3C-I). However, G. aureolum did not feed on larger algal species that had ESDs $\geq 12 \mu \mathrm{m}$ (e.g. the dinoflagellates Prorocentrum minimum, Heterocapsa triquetra, Scrippsiella trochoidea, Cochlodinium polykrikoides, P. micans, Akashiwo sanguinea, Gonyaulax polygramma, Alexandrium tamarense, and Lingulodinium polyedrum) or on Skeletonema costatum (Table 1). 

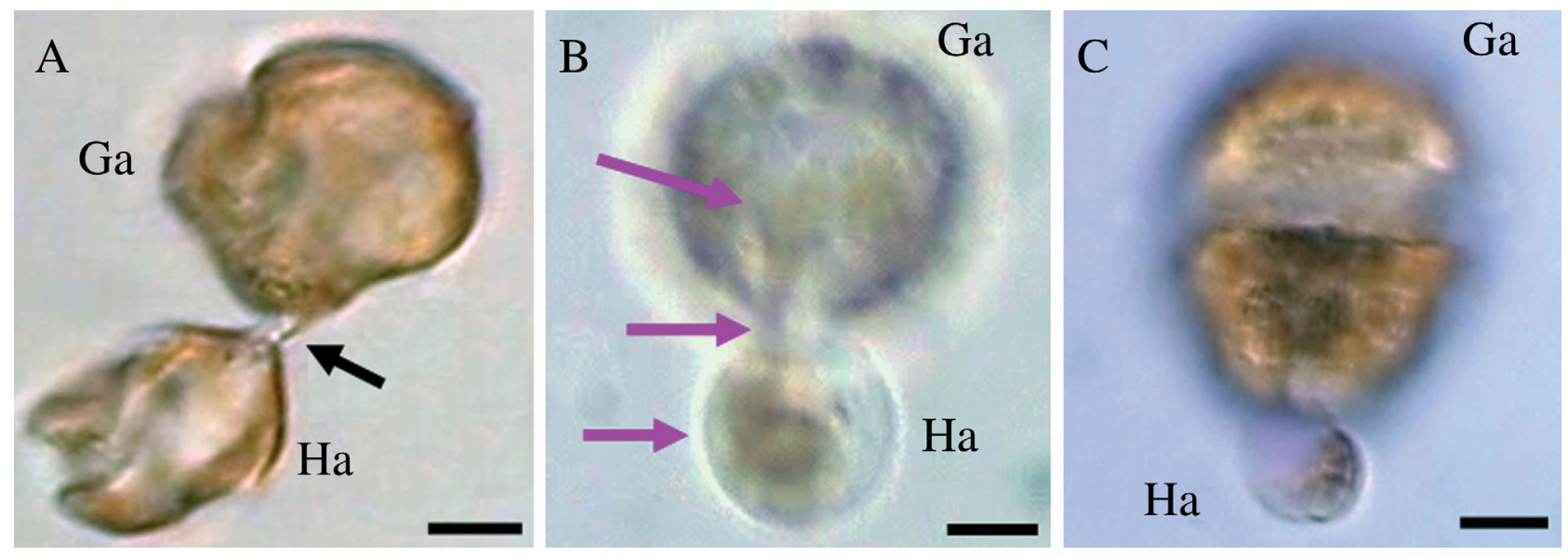

Fig. 4. Gymnodinium aureolum and Heterosigma akashiwo. Feeding process of G. aureolum (Ga) on H. akashiwo (Ha). (A) G. aureolum ingesting Ha prey cytoplasm through the peduncle (black arrow). (B) Transfer of prey materials (pink arrows) from prey to a food vacuole inside the protoplasm of $G$. aureolum through the peduncle. (C) Shrunken prey cell after feeding upon by

G. aureolum. Scale bars $=5 \mu \mathrm{m}$

\section{Expt 2: feeding mechanism}

Gymnodinium aureolum attached to individual prey cells with a tow filament and ingested entire prey cells through a peduncle (Fig. 4). The tow filament was 2 to $7 \mu \mathrm{m}$ in length before the peduncle was deployed. The time (mean $\pm \mathrm{SE}, \mathrm{n}=3$ ) between the deployment of a tow filament and a peduncle was $27 \pm 7 \mathrm{~s}$ for Teleaulax sp. Prey were transferred into the predator cell through the peduncle. For G. aureolum feeding on Teleaulax sp., the time from deployment of the peduncle to complete ingestion of the prey cell was $268 \pm 54 \mathrm{~s}$. Up to 2 to 3 G. aureolum cells were observed simultaneously attached to a single prey cell.

The other edible prey species tested in the present study were ingested by a Gymnodinium aureolum cell in the same manner as the Teleaulax sp. prey.

Table 3. Gymnodinium aureolum. Comparison of growth $\left(\mu, \mathrm{d}^{-1}\right)$ and ingestion rates $\left(\mathrm{ng} C\right.$ grazer $\left.^{-1} \mathrm{~d}^{-1}\right)($ mean $\pm \mathrm{SE}, \mathrm{n}=3)$ of $G$. aureolum on cryptophytes $(\mathrm{CR})$, dinoflagellates $(\mathrm{DN})$, prymnesiphytes (PR), and raphidophytes (RA) at single mean prey concentrations (MPC, ng $\mathrm{C} \mathrm{ml}^{-1}$ ). ESD: equivalent spherical diameter $(\mu \mathrm{m})$

\begin{tabular}{|lcccc|}
\hline Prey species & ESD & MPC & Growth rate & Ingestion rate \\
\hline Isochrysis galbana (PR) & 4.8 & $1448 \pm 12$ & $0.155 \pm 0.014$ & $0.057 \pm 0.005$ \\
Teleaulex sp. (CR) & 5.6 & $1596 \pm 59$ & $0.153 \pm 0.003$ & $0.043 \pm 0.009$ \\
Heterocapsa rotundata (DN) & 5.8 & $1866 \pm 49$ & $0.144 \pm 0.002$ & $0.068 \pm 0.014$ \\
Rhodomonas salina (CR) & 8.8 & $1558 \pm 71$ & $0.136 \pm 0.005$ & $0.021 \pm 0.010$ \\
Amphidinium carterae (DN) & 9.7 & $1722 \pm 61$ & $0.140 \pm 0.010$ & $0.050 \pm 0.025$ \\
Heterosigma akashiwo (RA) & 11.5 & $2002 \pm 15$ & $0.135 \pm 0.002$ & $0.040 \pm 0.010$ \\
Control (without added prey) & & 0 & $0.101 \pm 0.014$ & \\
\hline
\end{tabular}

\section{Expt 3: comparison of growth and ingestion rates at a single prey concentration}

We measured the growth and ingestion rates of Gymnodinium aureolum on 6 edible prey species at a single prey concentration (Table 3 ). When the mean prey concentration was ca. 1450 to $2000 \mathrm{ng} \mathrm{C} \mathrm{ml}^{-1}$, the specific growth rate (mixotrophic growth) of G. aureolum on Isochrysis galbana $\left(0.155 \mathrm{~d}^{-1}\right)$, Teleaulax sp. $\left(0.153 \mathrm{~d}^{-1}\right)$, Heterocapsa rotundata $\left(0.144 \mathrm{~d}^{-1}\right)$, Rhodomonas salina $\left(0.136 \mathrm{~d}^{-1}\right)$, Amphidinium carterae $\left(0.140 \mathrm{~d}^{-1}\right)$, or Heterosigma akashiwo $\left(0.135 \mathrm{~d}^{-1}\right)$ was significantly higher than that without added prey $\left(0.101 \mathrm{~d}^{-1}\right.$; autototrophic growth; 1-tailed $t$-test, $\mathrm{p}<$ 0.05 for $I$. galbana and A. carterae and $\mathrm{p}<0.01$ for all others). However, the mixotrophic growth rates of G. aureolum on these 6 algal prey species were not significantly different (ANOVA, $\mathrm{p}>0.1$ ).

The ingestion rates of Gymnodinium aureolum on the algal prey were $0.068 \mathrm{ng} \mathrm{C}$ grazer $^{-1} \mathrm{~d}^{-1}$ for Heterocapsa rotundata, $0.057 \mathrm{ng} \mathrm{C}$ grazer $^{-1} \mathrm{~d}^{-1}$ for Isochrysis galbana, $0.050 \mathrm{ng} \mathrm{C}$ grazer $^{-1} \mathrm{~d}^{-1}$ for Amphidinium carterae, $0.043 \mathrm{ng} \mathrm{C}$ grazer $^{-1}$ $\mathrm{d}^{-1}$ for Teleaulax sp., $0.040 \mathrm{ng} \mathrm{C}$ grazer $^{-1} \mathrm{~d}^{-1}$ for Heterosigma akashiwo, and $0.021 \mathrm{ng} \mathrm{C}$ grazer ${ }^{-1} \mathrm{~d}^{-1}$ for Rhodomonas salina. However, the ingestion rates of $G$. aureolum on these 6 algal prey species were not significantly different (ANOVA, $\mathrm{p}>0.1$ ).

Both growth and ingestion rates of Gymnodinium aureolum on the 6 edi- 

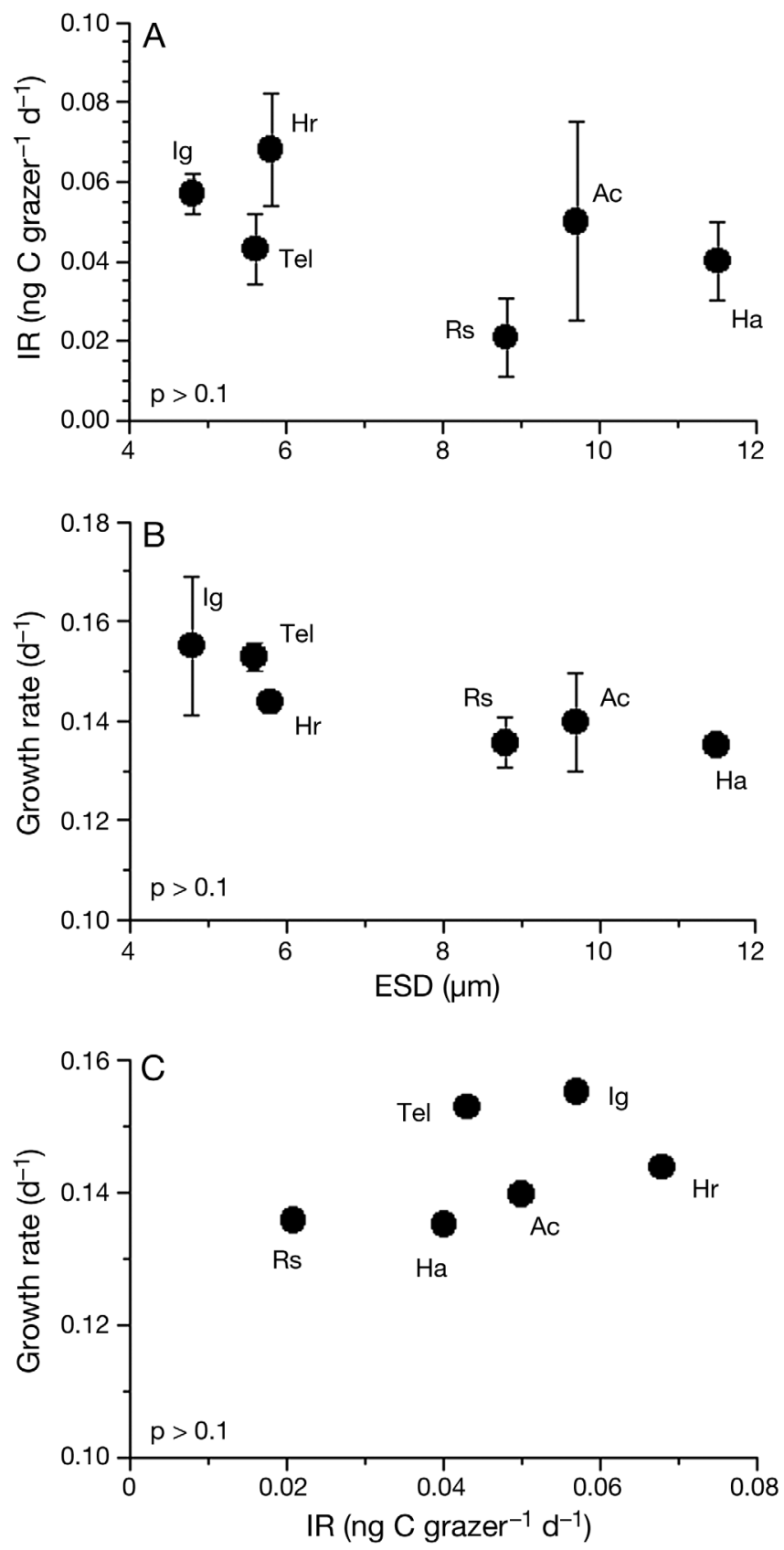

Fig. 5. Gymnodinium aureolum. (A) Ingestion rate (IR) and (B) growth rate $(\mu)$ of $G$. aureolum on the 6 edible prey as a function of prey size (equivalent spherical diameter [ESD], $\mu \mathrm{m})$ and (C) $\mu$ as a function of IR (see Table 3). Ac: Amphidinium carterae; Hr: Heterocapsa rotundata; Ha: Heterosigma akashiwo; Ig: Isochrysis galbana; Rs: Rhodomonas salina; Tel: Teleaulax sp. Data are means $(\mathrm{A}-\mathrm{C}) \pm 1 \mathrm{SE}(\mathrm{A}, \mathrm{B})$. All $\mathrm{p}>0.1$

ble prey were not significantly correlated with prey size (linear regression, $\mathrm{p}>0.1$; Fig. 5A, B). Moreover, the growth rates of $G$. aureolum on the 6 edible prey were not significantly correlated with their ingestion rates (p > 0.1; Fig. 5C).

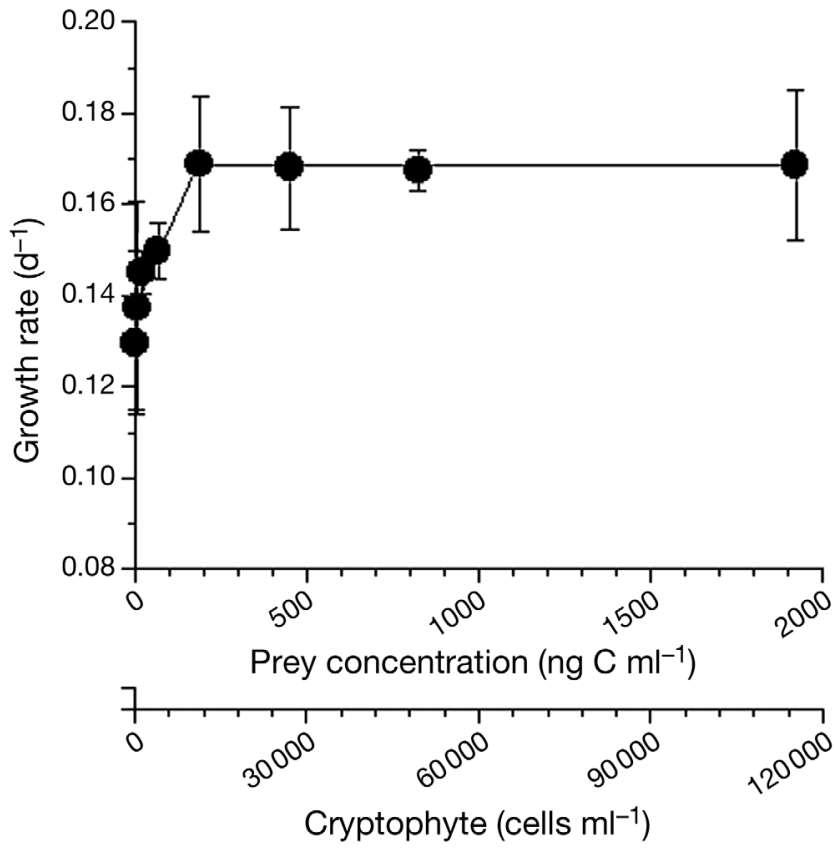

Fig. 6. Gymnodinium aureolum. Specific growth rates $\left(\mu, \mathrm{d}^{-1}\right)$ of G. aureolum feeding on Teleaulax sp. as a function of mean prey concentration $\left(x, \mathrm{ng} \mathrm{C} \mathrm{ml}{ }^{-1}\right)$. Symbols represent treatment means $\pm 1 \mathrm{SE}$. The curve is fitted by the linear regression equation using all the treatments in the experiment. For mean prey concentrations $\leq 188 \mathrm{ng} \mathrm{C} \mathrm{ml}^{-1}, \mu=0.00021 \mathrm{x}+$ $0.133, \mathrm{r}^{2}=0.360$; for the higher prey concentration, $\mu=0.169$

\section{Expt 4: effects of prey concentration}

The specific growth rates of Gymnodinium aureolum increased rapidly with increasing mean prey concentration before saturating at a Teleaulax sp. concentration of ca. $190 \mathrm{ng} \mathrm{C} \mathrm{ml}^{-1}$ (11050 cells ml-1) (Fig. 6). At the given prey concentrations, the highest specific growth rate (mixotrophic growth) of G. aureolum on Teleaulax sp. at $20^{\circ} \mathrm{C}$ under a $14 \mathrm{~h}$ light: $10 \mathrm{~h}$ dark cycle at $20 \mu \mathrm{E} \mathrm{m} \mathrm{m}^{-2} \mathrm{~s}^{-1}\left(0.169 \mathrm{~d}^{-1}, \mathrm{n}=3\right)$ was significantly higher than its growth rate (autotrophic growth) under the same light conditions without added prey $\left(0.120 \mathrm{~d}^{-1}, \mathrm{n}=21\right.$; 1 -tailed $t$-test, $\left.\mathrm{p}<0.01\right)$.

The ingestion rates of Gymnodinium aureolum feeding on Teleaulax sp. increased rapidly with increasing mean prey concentration before saturating at a Teleaulax sp. concentration of ca. $820 \mathrm{ng} \mathrm{C} \mathrm{ml}^{-1}$ (48 400 cells $\mathrm{ml}^{-1}$ ) (Fig. 7). At the given prey concentrations, the highest ingestion rate of $G$. aureolum on Teleaulax sp. was $0.047 \mathrm{ng} C$ grazer ${ }^{-1} \mathrm{~d}^{-1}$ (2.8 cells grazer $\left.{ }^{-1} \mathrm{~d}^{-1}\right)$. When the data were fitted to Eq. (2), the maximum ingestion rate of $G$. aureolum on Teleaulax sp. was 0.058 ng C grazer ${ }^{-1} \mathrm{~d}^{-1}$ (3.4 cells grazer ${ }^{-1} \mathrm{~d}^{-1}$ ) and $K_{\mathrm{IR}}$ (the prey concentration sustaining $1 / 2 I_{\max }$ ) was $706 \mathrm{ng} \mathrm{C}$ $\mathrm{ml}^{-1}$ (41530 cells ml-1 $\mathrm{m}^{-1}$. The maximum clearance rate of G. aureolum on Teleaulax sp. was $0.003 \mu$ grazer $^{-1} \mathrm{~h}^{-1}$. 


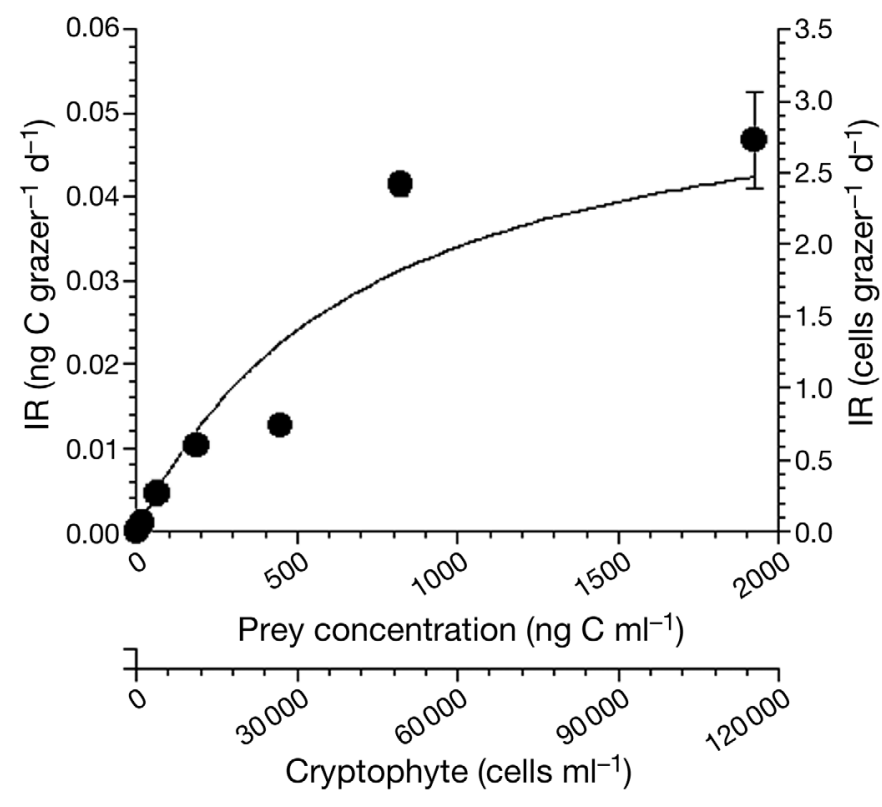

Fig. 7. Gymnodinium aureolum. Ingestion rates (IR, ng C grazer $^{-1} \mathrm{~d}^{-1}$ ) of $G$. aureolum feeding on Teleaulax sp. as a function of mean prey concentration $(x)$. Symbols represent treatment means \pm 1 SE. The curve is fitted by a MichaelisMenten equation (Eq. 2) using all the treatments in the experiment. IR $=0.058[x /(706+x)], r^{2}=0.892$

\section{Potential grazing impact}

The grazing coefficient attributable to Gymnodinium aureolum on co-occurring cryptophytes in the waters off Saemankeum, Korea in 2006-2008 ( $\mathrm{n}=36)$, when the abundances of cryptophytes and G. aureolum were 1 to 4270 cells $\mathrm{ml}^{-1}$ and 14 to 4425 cells $\mathrm{ml}^{-1}$, respectively, ranged from 0.001 to $0.498 \mathrm{~d}^{-1}$ (Fig. 8).

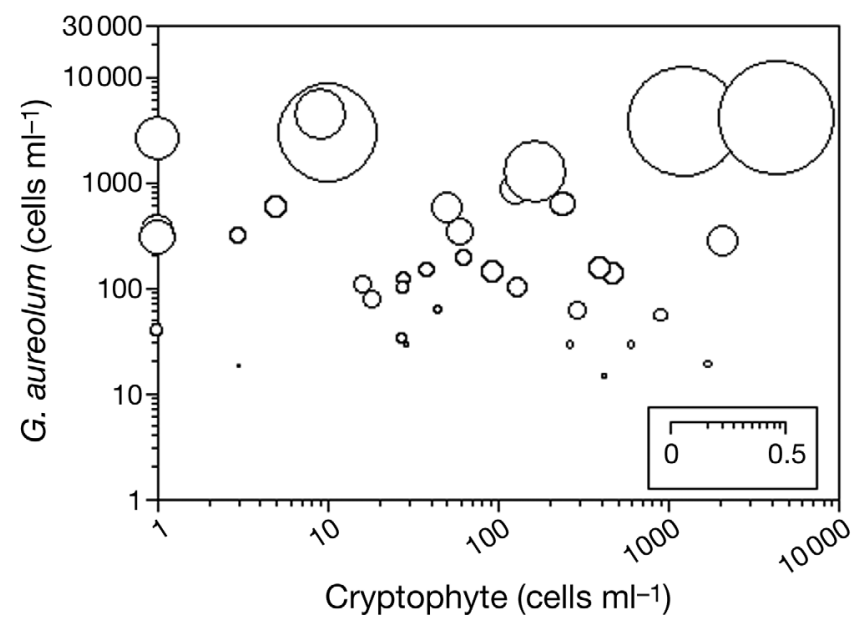

Fig. 8. Gymnodinium aureolum. Calculated grazing coefficients $\left(g, \mathrm{~d}^{-1}\right)$ attributable to $G$. aureolum on co-occurring cryptophytes (see 'Materials and methods' for calculation).

$$
\mathrm{n}=36
$$

\section{Swimming speed}

The swimming speed of Gymnodinium aureolum starved for 1 to $2 \mathrm{~d}$ was 200 to $576 \mu \mathrm{m} \mathrm{s}^{-1}$ (mean $\pm \mathrm{SE}=$ $394 \pm 16 \mu \mathrm{m} \mathrm{s}^{-1}, \mathrm{n}=30$ ).

\section{DISCUSSION}

\section{Gymnodinium aureolum isolated from Korean waters}

This is the first study on the occurrence of red tides dominated by Gymnodinium aureolum in Korean waters since the confusion regarding the taxonomy of G. aureolum and Karenia mikimotoi was resolved in 2000 (Daugbjerg et al. 2000, Hansen et al. 2000). The morphology of this Korean strain of G. aureolum was very similar to that of $G$. aureolum described by Hansen et al. (2000), Daugbjerg et al. (2000), and Tang et al. (2008). Cell length and width of live cells of this Korean strain growing photosynthetically (18.0 to 28.4 and 11.6 to $21.2 \mu \mathrm{m}$, respectively) were similar to the ranges of the strains isolated from a tributary of Chesapeake Bay, Pettaquamscutt River, and small embayments in the Woods Hole area in Massachusetts, USA (14 to 47 and 11 to $43 \mu \mathrm{m}$; summarized by Tang et al. 2008). In addition, the sequences of rDNA of this Korean strain were the same or very similar to those of strains of $G$. aureolum isolated from a tributary of Chesapeake Bay, USA (Tang et al. 2008); the Pettaquamscutt River, USA (Hansen et al. 2000); the Benguela Current waters off Namibia; and the waters off Denmark (Hansen et al. 2000), Australia (de Salas et al. 2003), and New Zealand (de Salas et al. 2005). Therefore, this Korean strain of $G$. aureolum was confirmed to be conspecific with strains isolated from the waters of other countries, indicating that G. aureolum has a worldwide distribution with very low variation in rDNA sequence (1 to $5 \mathrm{bp}$ difference).

\section{Toxicity}

Institutions in several countries have established monitoring programs for species known to form red tides (e.g. the National Fisheries Research and Development Institution, www.nfrdi.re.kr/en, and the Florida Fish and Wildlife Conservation Commission, www.redtideonline.com). During blooms of toxic redtide species, harvesting of shellfish or finfish is not permitted; however, fisheries remain open for harvest if blooms of non-toxic species occur. Therefore, determining whether a bloom species is a toxin producer is critical for the management of fisheries impacted by 
harmful algal blooms. The results of the present study indicate that the Korean strain of Gymnodinium aureolum is not toxic. However, a morphologically similar dinoflagellate, Karenia mikimotoi, is a known toxin producer (Gill \& Harris 1987, Hansen 1995, Smolowitz \& Shumway 1997), and accurate differentiation between these species is important.

\section{Prey species and feeding mechanism}

The present study is the first to reveal that Gymnodinium aureolum is a mixotrophic dinoflagellate. Thus mixotrophy in G. aureolum should be considered in exploring the outbreak, persistence, and decline of red tides dominated by this species. G. aureolum is able to feed on heterotrophic bacteria, Synechococcus sp., and algal prey with an ESD of $\leq 11.5 \mu \mathrm{m}$, except the diatom Skeletonema costatum. The algal species that G. aureolum was able to feed on in the present study are similar to that of the mixotrophic dinoflagellates Cochlodinium polykrikoides, Gymnodinium impudicum, and Prorocentrum minimum, which engulf prey cells through the sulcus or suture (Jeong et al. 2004, 2005c) and the newly described mixotrophic dinoflagellate Paragymnodinium shiwhaense, which feeds on prey cells using a peduncle (Yoo et al. 2010). If G. aureolum and these mixotrophic dinoflagellates co-occur, there may be competition for common algal prey species, regardless of the size $(\mathrm{ESD}=12$ to $26 \mu \mathrm{m})$, maximum swimming speed (190 to $1450 \mu \mathrm{m} \mathrm{s}^{-1}$ ), and feeding mechanisms of these dinoflagellates (Jeong et al. 1999, 2005c).

Gymnodinium aureolum ingested algal prey using a peduncle. Although the presence of a peduncle structure previously has been reported for G. aureolum (Hansen 2001), the present study is the first to observe the use of the peduncle for ingestion of prey cells. The mixotrophic dinoflagellates Paragymnodinium shiwhaense and Karlodinium armiger and the heterotrophic dinoflagellates Pfiesteria piscicida, Pfiesteria shumwayae, Stoeckeria algicida, and Luciella masanensis also feed on algal prey using a peduncle (Burkholder \& Glasgow 1997, Jeong et al. 2005a, 2006, 2007 , Berge et al. 2008, Yoo et al. 2010). Therefore, the use of the peduncle among mixotrophic and heterotrophic dinoflagellates with a cell length of 10 to $30 \mu \mathrm{m}$ appears to be relatively common. Peduncle feeders generally are able to feed on larger prey than engulfment feeders of a similar size. Therefore, the peduncle enables small dinoflagellates to feed on prey species with a wider size range compared to similar-sized engulfment-feeding dinoflagellates.

Like Karlodinium armiger and Paragymnodinium shiwhaense, Gymnodinium aureolum did not feed on
Skeletonema costatum, whereas Pfiesteria piscicida and Luciella masanensis are known to feed on this diatom (Jeong et al. 2006, 2007, Berge et al. 2008, Yoo et al. 2010). These peduncle-feeding mixotrophic dinoflagellates do not seem to have peduncles that are strong enough to penetrate the frustules of the diatom, while the peduncle-feeding heterotrophic dinoflagellates seem to have strong peduncles. However, many engulfment-feeding mixotrophic dinoflagellates with ESDs $\geq 5.8 \mu \mathrm{m}$ are able to feed on $S$. costatum (Yoo et al. 2009). Therefore, in feeding by mixotrophic dinoflagellates on the diatom, engulfment-feeding seems to be more effective than peduncle-feeding.

\section{Comparison of growth and ingestion rates}

When the mean prey concentration was similar, the growth rate (mixotrophic growth) of Gymnodinium aureolum on Isochrysis galbana, Teleaulax sp., Heterocapsa rotundata, Rhodomonas salina, Amphidinium carterae, or Heterosigma akashiwo was significantly higher than that without the added prey (autotrophic growth). This evidence suggests that phagotrophy in G. aureolum clearly increases its growth rate. However, the mixotrophic growth rates and ingestion rates of $G$. aureolum on these 6 algal prey species were not significantly different. Therefore, it can be speculated that $G$. aureolum may not have preferences for a particular prey species. Unlike with G. aureolum, I. galbana and $H$. rotundata did not support positive growth $\left(-0.148\right.$ to $\left.-0.158 \mathrm{~d}^{-1}\right)$ of another peduncle-feeding mixotrophic dinoflagellate Paragymnodinium shiwhaense, even though $P$. shiwhaense ingested I. galbana and H. rotundata (Yoo et al. 2010). Thus G. aureolum may outgrow $P$. shiwhaense when I. galbana and $H$. rotundata are abundant in natural environments.

\section{Effects of prey concentration}

Both the growth and ingestion rates of Gymnodinium aureolum feeding on a unialgal diet of Teleaulax sp. were affected by the prey concentration. The mean prey concentration at which the growth rate (mixotrophic growth) of G. aureolum on Teleaulax sp. under a 14:10 h light:dark cycle at $20 \mu \mathrm{E} \mathrm{m} \mathrm{m}^{-2} \mathrm{~s}^{-1}$ became saturated (ca. $190 \mathrm{ng} \mathrm{C} \mathrm{ml}^{-1}$ ) was comparable to that for Heterocapsa triquetra (110 $\mathrm{ng} \mathrm{C} \mathrm{ml}^{-1}$ ) and

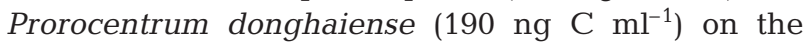
same prey under the same conditions, while it was considerably lower than that for $P$. micans (430 $\mathrm{ng} \mathrm{C} \mathrm{ml}^{-1}$ ) and Gonyaulax polygramma (600 $\mathrm{ng} \mathrm{C} \mathrm{ml}^{-1}$ ) (Jeong et al. 2005c,d). All of these dinoflagellates co-occur sometimes in coastal waters (e.g. Marshall 1980, Jacobson 
1987, Yoo et al. 2002, H. J. Jeong et al. unpubl. data). Therefore, when the abundance of Teleaulax sp. increases under a $14 \mathrm{~h}$ light:10 h dark cycle of $20 \mu \mathrm{E} \mathrm{m} \mathrm{m}^{-2}$ $\mathrm{s}^{-1}$, the concentration of $H$. triquetra may reach its maximum, followed by an increase in the concentrations of $G$. aureolum and/or $P$. donghaiense, and a subsequent possible increase in the concentrations of P. micans and/or G. polygramma.
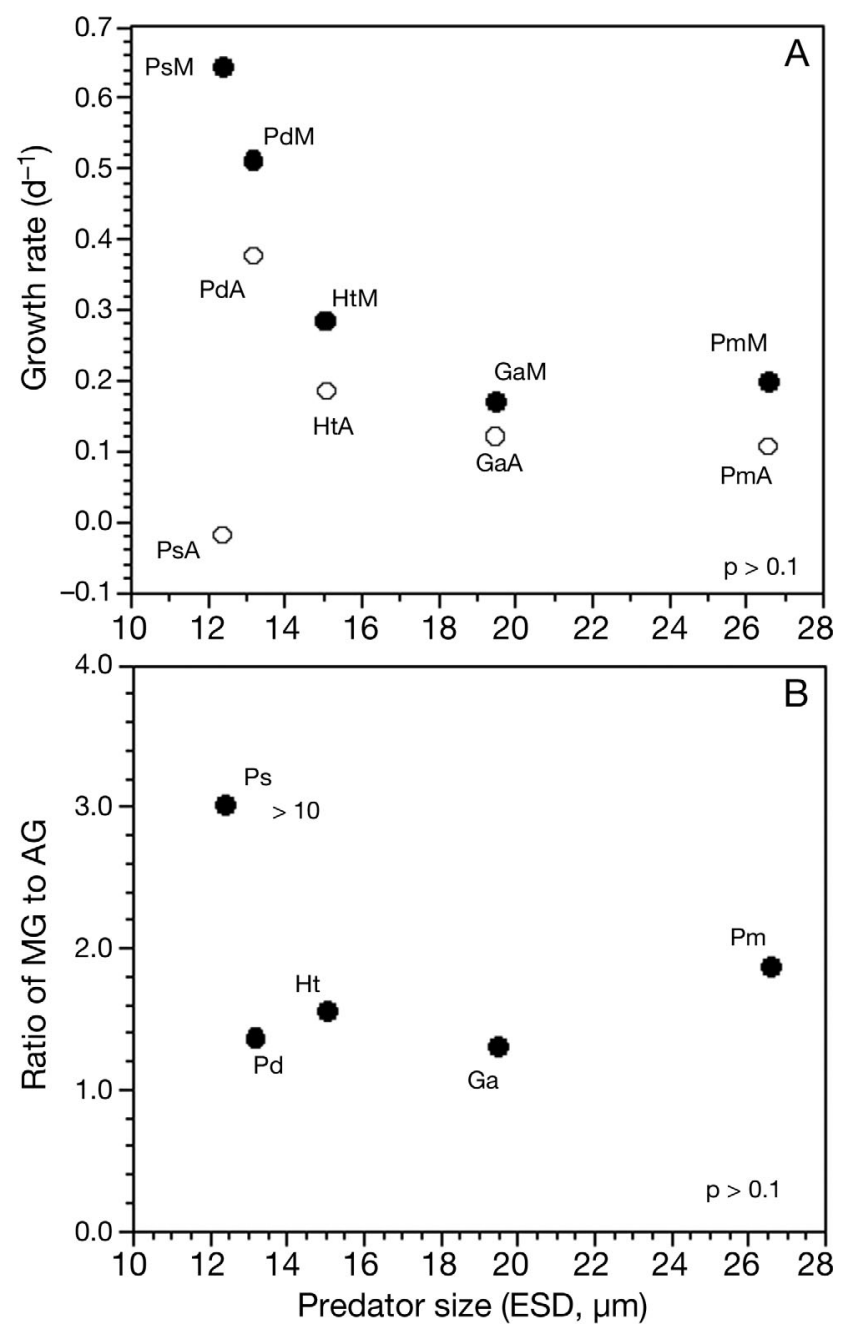

Fig. 9. (A) Maximum mixotrophic growth rate (MG) of 5 mixotrophic dinoflagellates feeding on Teleaulax sp. (previously unidentified cryptophyte, equivalent spherical diameter $[\mathrm{ESD}]=5.6 \mu \mathrm{m})$ and their autotrophic growth rate $(\mathrm{AG}$; predator control) obtained under a $14 \mathrm{~h}$ light:10 h dark cycle at $20 \mu \mathrm{E} \mathrm{m} \mathrm{m}^{-2} \mathrm{~s}^{-1}$ and (B) the ratio of MG to AG as a function of predator size (ESD). The p-values for both MG and AG in (A) and (B) were all >0.1. GaM/A: mixotrophic/autotrophic growth rate of Gymnodinium aureolumi HtM/A: mixotrophic/ autotrophic growth rate of Heterocapsa triquetra; PdM/A: mixotrophic/autotrophic growth rate of Prorocentrum donghaiense; PmM/A: mixotrophic/autotrophic growth rate of Prorocentrum micans, PsM/A: mixotrophic/autotrophic growth rate of Paragymnodinium shiwhaense. Ga: G. aureolum; Ht: H. triquetra; Pd: P. donghaiense; Pm: P. minimum; Ps: $P$. shiwhaense
The maximum growth rate (mixotrophic growth) of Gymnodinium aureolum on Teleaulax sp. obtained under a $14 \mathrm{~h}$ light:10 h dark cycle at $20 \mu \mathrm{E} \mathrm{m} \mathrm{m}^{-2} \mathrm{~s}^{-1}(0.17$ $\mathrm{d}^{-1}$ ) was lower than that of the mixotrophic dinoflagellates Gonyaulax polygramma, Heterocapsa triquetra, Paragymnodinium shiwhaense, Prorocentrum donghaiense, and Prorocentrum micans on the same prey under the same conditions (0.2 to $1.1 \mathrm{~d}^{-1}$; Fig. 9A), while the autotrophic growth rate of G. aureolum $(0.10$ to $0.12 \mathrm{~d}^{-1}$ ) was comparable to that of the other mixotrophic dinoflagellates ( 0.11 to $\left.0.38 \mathrm{~d}^{-1}\right)$. This evidence suggests that, if Teleaulax sp. is abundant and these mixotrophic dinoflagellates co-occur, G. aureolum may be outcompeted by these mixotrophic dinoflagellates. At the light intensity of $20 \mu \mathrm{E} \mathrm{m} \mathrm{m}^{-2} \mathrm{~s}^{-1}$, the ratio of mixotrophic growth relative to autotrophic growth of $G$. aureolum (1.4 to 1.5) was similar to that of P. donghaiense (1.4) and Heterocapsa triquetra (1.5), but lower than that of the other mixotrophic dinoflagellates $(1.9$ to $>10)$ (Fig. 9B). This evidence suggests that phagotrophy in G. aureolum may contribute less to gaining energy than photosynthesis compared to the other mixotrophic dinoflagellates (except $P$. donghaiense and $H$. triquetra).

The highest or maximum ingestion rate of Gymnodinium aureolum on Teleaulax sp. obtained in the present study (0.043 to $0.058 \mathrm{ng} \mathrm{C}_{\text {grazer }}{ }^{-1} \mathrm{~d}^{-1}$ ) was higher than that of Prorocentrum donghaiense (0.026 ng $\mathrm{C}$ grazer $^{-1} \mathrm{~d}^{-1}$ ) and Heterocapsa triquetra (0.038) on the same prey under the same conditions, comparable to $P$. micans (0.041) (Jeong et al. 2005c), and much lower than that of Gonyaulax polygramma (0.18 ng C grazer $^{-1} \mathrm{~d}^{-1}$ ) (Jeong et al. 2005d). G. aureolum (ESD = $19 \mu \mathrm{m})$ is larger than $P$. donghaiense $(\mathrm{ESD}=13.3 \mu \mathrm{m})$ and $H$. triquetra $(\mathrm{ESD}=15.0 \mu \mathrm{m})$, but much smaller than G. polygramma (ESD $=32.5 \mu \mathrm{m})$. Therefore, the highest or maximum ingestion rates of these mixotrophic dinoflagellates including $G$. aureolum on Teleaulax sp. at $20^{\circ} \mathrm{C}$ under a $14: 10 \mathrm{~h}$ light:dark cycle at $20 \mu \mathrm{E} \mathrm{m}^{-2} \mathrm{~s}^{-1}$ is likely to be affected by the size of the predators.

\section{Grazing impact}

The calculated grazing coefficient attributable to Gymnodinium aureolum on co-occurring cryptophytes obtained in the present study ranged up to $0.498 \mathrm{~d}^{-1}$ (i.e. up to $39 \%$ of the cryptophyte populations were removed by $G$. aureolum populations in $1 \mathrm{~d}$ ). The results of the present study suggest that G. aureolum may sometimes have a considerable grazing impact on the populations of co-occurring cryptophytes. In addition, the peak of G. aureolum is likely to follow that of the cryptophytes. However, the presence of alternative 
prey may lower grazing impact by G. aureolum on cooccurring cryptophytes in natural environments because $G$. aureolum may not have preferences for a particular prey species among the 6 algal prey species used in the present study. Some studies have reported that the peak of other mixotrophic red-tide dinoflagellates such as Karlodinium veneficum and Dinophysis fortii followed that of cryptophytes in natural environments on the basis of daily or weekly monitoring (Koike et al. 2007, Adolf et al. 2008, Burkholder et al. 2008). In particular, Adolf et al. (2008) suggested that cryptophyte abundance would be a key factor supporting blooms of $K$. veneficum. To understand the population dynamics of $G$. aureolum and cryptophytes and their interaction, the daily or at least weekly variations in the abundances of $G$. aureolum and cryptophytes in natural environments need to be explored.

Currently, using the morphology and DNA sequence analyses, we can identify Gymnodinium aureolum and distinguish it from Karenia mikimotoi (Daugbjerg et al. 2000, Hansen et al. 2000, Tang et al. 2008, present study). Thus it is possible to explore the presence and abundance of $G$. aureolum in many countries. More data on the abundance of $G$. aureolum and specific prey species are needed to estimate the grazing impact of $G$. aureolum.

Acknowledgements. We thank J. S. Kim, E. Y. Yoon, and K. H. Lee for technical support. This paper was funded by grants from the National Research Foundation (2009-0058298) and the Ecological Disturbance Research Program Korea Institute of Marine Science \& Technology Promotion (KIMST), Ministry of Land, Transportation and Marine Affairs (KMLTM) award to H.J.J., and a grant from the Korea Rural Community Cooperation (SH-03-01-02-08) and the Infrastructuring Grant for Marine Biotechnology Program funded by KMLTM to W.H.Y.

\section{LITERATURE CITED}

Adolf JE, Bachvaroff T, Place AR (2008) Can cryptophyte abundance trigger toxic Karlodinium veneficum blooms in eutrophic estuaries? Harmful Algae 8:119-128

Berge T, Hansen PJ, Moestrup Ø (2008) Prey size spectrum and bioenergetics of the mixotrophic dinoflagellate Karlodinium armiger. Aquat Microb Ecol 50:289-299

Bergholtz T, Daugbjerg N, Moestrup Ø (2006) On the identity of Karlodinium veneficum and description of Karlodinium armiger sp. nov. (Dinophyceae), based on light and electron microscopy, nuclear-encoded LSU rDNA, and pigment composition. J Phycol 42:170-193

Blasco D, Berard-Therriault L, Levasseur M, Vrieling EG (1996) Temporal and spatial distribution of the ichthyotoxic dinoflagellate Gyrodinium aureolum Hulburt in the St Lawrence, Canada. J Plankton Res 18:1917-1930

> Bockstahler KR, Coats DW (1993) Spatial and temporal aspects of mixotrophy in Chesapeake Bay dinoflagellates. J Eukaryot Microbiol 40:49-60

Burkholder JM, Glasgow HB Jr (1997) Trophic controls on stage transformations of a toxic ambush-predator dinofla- gellate. J Eukaryot Microbiol 44:200-205

Burkholder JM, Glibert PM, Skelton HM (2008) Mixotrophy, a major mode of nutrition for harmful algal species in eutrophic waters. Harmful Algae 8:77-93

Daugbjerg N, Hansen G, Larsen J, Moestrup Ø (2000) Phylogeny of some of the major genera of dinoflagellates based on ultrastructure and partial LSU rDNA sequence data, including the erection of three new genera of unarmoured dinoflagellates. Phycologia 39:302-317

de Salas MF, Bolch CJS, Botes L, Nash G, Wright SW, Hallegraeff GM (2003) Takayama gen. nov. (Gymnodiniales, Dinophyceae), a new genus of unarmoured dinoflagellates with sigmoid apical grooves, including the description of two new species. J Phycol 39:1233-1246

de Salas MF, Bolch CJ, Hallegraeff GM (2005) Karlodinium australe sp. nov. (Gymnodiniales, Dinophyceae), a new potentially ichthyotoxic unarmoured dinoflagellate from lagoonal habitats of south-eastern Australia. Phycologia 44:640-650

Frost BW (1972) Effects of size and concentration of food particles on the feeding behavior of the marine planktonic copepod Calanus pacificus. Limnol Oceanogr 17:805-815

Gill CW, Harris RP (1987) Behavioural responses of the copepods Calanus helgolandicus and Temora longicornis to dinoflagellate diets. J Mar Biol Assoc UK 67:785-801

Glibert PM, Burkholder JM, Kana TM, Alexander J, Skelton H, Shilling C (2009) Grazing by Karenia brevis on Synechococcus enhances its growth rate and may help to sustain blooms. Aquat Microb Ecol 55:17-30

Guillard RRL, Ryther JH (1962) Studies of marine planktonic diatoms. I. Cyclotella nana Hustedt and Detonula confervacea (Cleve) Grun. Can J Microbiol 8:229-239

- Hansen G (2001) Ultrastructure of Gymnodinium aureolum (Dinophyceae): toward a further redefinition of Gymnodinium sensu stricto. J Phycol 37:612-623

> Hansen G, Daugbjerg N, Henriksen P (2000) Comparative study of Gymnodinium mikimotoi and Gymnodinium aureolum, comb. nov. (=Gyrodinium aureolum) based on morphology, pigment composition, and molecular data. J Phycol 36:394-410

> Hansen PJ (1995) Growth and grazing response of a ciliate feeding on the red tide dinoflagellate Gyrodinium aureolum in monoculture and in mixture with a non-toxic alga. Mar Ecol Prog Ser 121:65-72

> Hansen PJ, Nielsen TG (1997) Mixotrophic feeding of Fragilidium subglobosum (Dinophyceae) on three species of Ceratium: effects of prey concentration, prey species and light intensity. Mar Ecol Prog Ser 147:187-196

Hansen PJ, Bjornsen PK, Hansen BW (1997) Zooplankton grazing and growth: scaling within the $2-2000 \mu \mathrm{m}$ body size range. Limnol Oceanogr 42:687-704

> Heinbokel JF (1978) Studies on the functional role of tintinnids in the Southern California Bight. I. Grazing and growth rates in laboratory cultures. Mar Biol 47:177-189

- Huelsenbeck JP, Ronquist F (2001) MrBayes: Bayesian inference of phylogeny. Bioinformatics 17:754-755

> Hulburt EM (1957) The taxonomy of unarmored Dinophyceae of shallow embayments on Cape Cod, Massachusetts. Biol Bull 112:196-219

Jacobson DM (1987) The ecology and feeding biology of thecate heterotrophic dinoflagellates. PhD dissertation, Woods Hole Oceanographic Institution, Massachusetts Institute of Technology, Woods Hole, MA

> Jeong HJ, Shim JH, Kim JS, Park JY, Lee CW, Lee Y (1999) Feeding by the mixotrophic thecate dinoflagellate Fragilidium cf. mexicanum on red-tide and toxic dinoflagellates. Mar Ecol Prog Ser 176:263-277 
Jeong HJ, Yoo YD, Kim JS, Kim TH, Kim JH, Kang NS, Yih WH (2004) Mixotrophy in the phototrophic harmful alga Cochlodinium polykrikoides (Dinophycean): prey species, the effects of prey concentration and grazing impact. J Eukaryot Microbiol 51:563-569

Jeong HJ, Kim JS, Kim JH, Kim ST and others (2005a) Feeding and grazing impact of the newly described heterotrophic dinoflagellate Stoeckeria algicida on the harmful alga Heterosigma akashiwo. Mar Ecol Prog Ser 295:69-78

Jeong HJ, Park JY, Nho JH, Park MO and others (2005b) Feeding by red-tide dinoflagellates on the cyanobacterium Synechococcus. Aquat Microb Ecol 41:131-143

Jeong HJ, Yoo YD, Park JY, Song JY and others (2005c) Feeding by phototrophic red-tide dinoflagellates: five species newly revealed and six species previously known to be mixotrophic. Aquat Microb Ecol 40:133-150

Jeong HJ, Yoo YD, Seong KA, Kim JH and others (2005d) Feeding by the mixotrophic red-tide dinoflagellate Gonyaulax polygramma: mechanisms, prey species, effects of prey concentration, and grazing impact. Aquat Microb Ecol 38:249-257

Jeong HJ, Ha JH, Park JY, Kim JH and others (2006) Distribution of the heterotrophic dinoflagellate Pfiesteria piscicida in Korean waters and its consumption of mixotrophic dinoflagellates, raphidophytes and fish blood cells. Aquat Microb Ecol 44:263-278

Jeong HJ, Ha JH, Yoo YD, Park JY and others (2007) Feeding by the Pfiesteria-like heterotrophic dinoflagellate Luciella masanensis. J Eukaryot Microbiol 54:231-241

Koike K, Nishiyama A, Takishita K, Kobiyama A, Ogata T (2007) Appearance of Dinophysis fortii following blooms of certain cryptophyte species. Mar Ecol Prog Ser 337: 303-309

Li A, Stoecker DK, Coats DW (2000) Mixotrophy in Gyrodinium galatheanum (dinophyceae): grazing responses to light intensity and inorganic nutrients. J Phycol 36:33-45

Marshall HG (1980) Seasonal phytoplankton composition in the lower Chesapeake Bay and Old Plantation Creek, Cape Charles, Virginia. Estuaries 3:207-216

Medlin L, Elwood HJ, Stickel S, Sogin ML (1988) The characterization of enzymatically amplified eukaryotic 16S-like rRNA-coding regions. Gene 71:491-499

Nielsen M, Tønseth CP (1991) Temperature and salinity effect on growth and chemical composition of Gyrodinium aureolum Hulburt in culture. J Plankton Res 11:391-407

Park MG, Kim SJ, Kim HS, Myung GO, Kang YG, Yih WH (2006) First successful culture of the marine dinoflagellate Dinophysis acuminata. Aquat Microb Ecol 45:101-106

Posada D, Crandall KA (1998) MODELTEST: testing the model of DNA substitution. Bioinformatics 14:817-818

Potts GW, Edwards JM (1987) Impact of a Gyrodinium aureolum bloom on inshore young fish populations. J Mar Biol Assoc UK 67:293-297

Editorial responsibility: Patricia Glibert, Cambridge, Maryland, USA
Seong KA, Jeong HJ, Kim S, Kim GH, Kang JH (2006) Bacterivory by co-occurring red-tide algae, heterotrophic nanoflagellates, and ciliates. Mar Ecol Prog Ser 322:85-97

> Sherr BF, Sherr EB, Fallon RD (1987) Use of monodispersed, fluorescently labeled bacteria to estimate in situ protozoan bacterivory. Appl Environ Microbiol 53:958-965

> Skovgaard A, Hansen PJ, Stoecker DK (2000) Physiology of the mixotrophic dinoflagellate Fragilidium subglobosum. I. Effects of phagotrophy and irradiance on photosynthesis and carbon content. Mar Ecol Prog Ser 201:129-136

> Smalley GW, Coats DW, Adam EJ (1999) A new method using fluorescent microspheres to determine grazing on ciliates by the mixotrophic dinoflagellate Ceratium furca. Aquat Microb Ecol 17:167-179

Smolowitz R, Shumway SE (1997) Possible cytotoxic effects of the dinoflagellate, Gyrodinium aureolum, on juvenile bivalve molluscs. Aquac Int 5:291-300

Spurr AR (1969) A low viscosity epoxy resin embedding medium for electron microscopy. J Ultrastruct Res 26: $31-42$

Stamatakis A (2006) RAxML-VI-HPC: maximum likelihoodbased phylogenetic analyses with thousands of taxa and mixed models. J Plankton Res 22:2688-2690

Stoecker DK (1999) Mixotrophy among dinoflagellates. J Eukaryot Microbiol 46:397-401

Stoecker DK, Li A, Coats DW, Gustafson DE, Nannen MK (1997) Mixotrophy in the dinoflagellate Prorocentrum minimum. Mar Ecol Prog Ser 152:1-12

Strathmann RR (1967) Estimating the organic carbon content of phytoplankton from cell volume or plasma volume. Limnol Oceanogr 12:411-418

> Tang YZ, Egerton TA, Kong L, Marshall HG (2008) Morphological variation and phylogenetic analysis of the dinoflagellate Gymnodinium aureolum from a tributary of Chesapeake Bay. J Eukaryot Microbiol 55:91-99

Tangen K (1977) Blooms of Gyrodinium aureolum (Dinophyceae) in north European waters, accompanied by mortality in marine organisms. Sarsia 63:123-133

Yoo YD, Jeong HJ, Shim JH, Park JY and others (2002) Outbreak of red tides in the coastal waters off the southern Saemankeum areas, Jeonbuk, Korea. 1. Temporal and spatial variations in the phytoplankton community in the summer-fall of 1999. The Sea 7:129-139 (in Korean with English abstract)

> Yoo YD, Jeong HJ, Kim MS, Kang NS and others (2009) Feeding by phototrophic red-tide dinoflagellates on the ubiquitous marine diatom Skeletonema costatum. J Eukaryot Microbiol 56:413-420

Yoo YD, Jeong HJ, Kang NS, Song JY, Kim KY, Lee KT, Kim JH (2010) Feeding by the newly described mixotrophic dinoflagellate Paragymnodinium shiwhaense: feeding mechanism, prey species, and effect of prey concentration. J Eukaryot Microbiol 57:145-158

Submitted: September 3, 2009; Accepted: December 11, 2009 Proofs received from author(s): April 12, 2010 